\title{
Stingless Bee-Collected Pollen (Bee Bread): Chemical and Microbiology Properties and Health Benefits
}

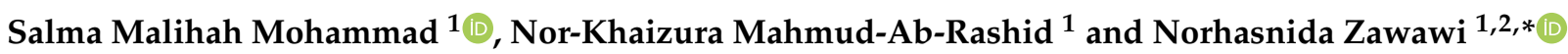 \\ 1 Department of Food Science, Faculty of Food Science and Technology, Universiti Putra Malaysia, Serdang \\ 43400, Selangor, Malaysia; salmamalihah94@gmail.com (S.M.M.); norkhaizura@upm.edu.my (N.-K.M.-A.-R.) \\ 2 Natural Medicines and Products Research Laboratory, Universiti Putra Malaysia, \\ Serdang 43400, Selangor, Malaysia \\ * Correspondence: norhasnida@upm.edu.my
}

Citation: Mohammad, S.M.;

Mahmud-Ab-Rashid, N.-K.; Zawawi,

N. Stingless Bee-Collected Pollen (Bee Bread): Chemical and Microbiology

Properties and Health Benefits.

Molecules 2021, 26, 957. https://

doi.org/10.3390/molecules26040957

Academic Editors: Nada Oršolić, Maja

Jazvinščak Jembrek and Lesław Juszczak

Received: 30 October 2020

Accepted: 6 December 2020

Published: 11 February 2021

Publisher's Note: MDPI stays neutral with regard to jurisdictional clai$\mathrm{ms}$ in published maps and institutional affiliations.

Copyright: (C) 2021 by the authors. Licensee MDPI, Basel, Switzerland. This article is an open access article distributed under the terms and conditions of the Creative Commons Attribution (CC BY) license (https:// creativecommons.org/licenses/by/ $4.0 /)$.

\begin{abstract}
Stingless bee-collected pollen (bee bread) is a mixture of bee pollen, bee salivary enzymes, and regurgitated honey, fermented by indigenous microbes during storage in the cerumen pot. Current literature data for bee bread is overshadowed by bee pollen, particularly of honeybee Apis. In regions such as South America, Australia, and Southeast Asia, information on stingless bee bee bread is mainly sought to promote the meliponiculture industry for socioeconomic development. This review aims to highlight the physicochemical properties and health benefits of bee bread from the stingless bee. In addition, it describes the current progress on identification of beneficial microbes associated with bee bread and its relation to the bee gut. This review provides the basis for promoting research on stingless bee bee bread, its nutrients, and microbes for application in the food and pharmaceutical industries.
\end{abstract}

Keywords: stingless bee; bee bread; fermented pollen; phenolic compounds; microbes

\section{Introduction}

Bees have a unique social life. In a social bee community, the queen dominates the reproduction and has a morphology different from other bees. The colonies live for many years (perennial) [1]. Stingless bee is an example of social bees alongside honeybee and bumblebee. It contains more than 50 genera and 600 species worldwide [2]. Stingless bee is different from other bee species. As its name implies, stingless bee's sting is significantly reduced [2] and is not an effective mechanism for nest protection, but it can still bite to protect its hive from threats.

Bee products are crucial for bee survival, and it is acquired for medicine, offering cosmetic, and everyday uses since $8000 \mathrm{BC}$ [3]. Gradually, modern beekeeping industry emerged, whereby beekeepers collect these products for commercial purposes or personal uses. Stingless bees are widely distributed in countries such as South America, Africa, Southeast Asia, and Australia [1], prompting ventures of stingless bee beekeeping industry in these local regions for socioeconomic development and biodiversity conservation.

Bee bread is one the bee by-products made from pollen collected by the bee added with nectar and bee salivary enzymes before it undergoes lactic acid fermentation in beehives [4]. Bee bread is also referred to as fermented pollen, pot-pollen, stored pollen, or ambrosia [4,5]. Occasionally, among researchers, it is used interchangeably with bee pollen. In this article, the term bee bread is used and strictly referred to as stored pollen collected from inside of the beehives.

Consumer interest and demand for natural products have influenced in-depth research for bee bread nutritional properties. Bee bread is rich in carbohydrate, protein, and lipids and contain other micronutrients such as minerals, vitamins, phenolic compounds, and essential amino acids [6]. It possesses therapeutic values such as anti-inflammatory 
properties, antioxidant properties, antimicrobial properties, antitumor activity, and antihypertensive activity $[6,7]$. Bee bread nutritional values are varied as factors such as botanical origin, geographical location, climatic conditions, soil type, beekeeper activities, and bee species contribute towards its chemical composition [8,9].

Research on bee pollen from European honeybee (Apis spp.) has been continuously reported $[4,6,10]$ overshadowing what bee bread can offer. One of the reasons is the difficulty in acquiring honeybee bee bread from the honeycomb [4]. This consequently influenced researchers' preference to study on bee pollen. However, bee pollen is biochemically different to bee bread [11] as the latter is a product of fermentation. This makes research on bee bread essential to distinguish between these bee products for the development of meliponiculture industry. Apiarists could profit from bee bread production, which could sustain bee-keeping industry by not relying solely on honey as a source of income.

The nutrient richness of bee bread simultaneously promotes the growth of microbes. For the bee, microbes are essential to protect bee colonies against pathogens and provide nutrients for bee growth [12]. There is plenty of studies reported on isolation and identification of bee bread microbes with profound interest on lactic acid bacteria $[13,14]$ because of its significant status as an industrially important group of bacteria. For instance, recent discoveries have identified bacteria from stingless bee bee bread as probiotic [15] and source of antimicrobial compounds and industrial enzymes [16] signifying the potential use of bee bread microbes in the food industry.

In this review paper, bee bread of stingless bee is introduced, highlighting its chemical composition and health benefits. In addition, microbes specifically associated with bee fermentation in relation to the bee gut are discussed.

\section{Stingless Bee Bee Bread: From Production to Harvesting}

The bee bread raw materials originate from the plant pollens. Pollens are fine granular substances produced by the plant anther containing male gametophyte (sperm cell), which are essential for plant reproduction. It is either distributed through the wind ("anemophilous" wind-pollinated) or by an insect ("entomophilous" - insect-pollinated). The global production of pollens was estimated as 1.36 million kg per year with China, Australia, and Argentina as the biggest contributors [4].

The process of stingless bee making bee bread begins from plant pollen, which is illustrated in Figure 1. Stingless bee can have an average flight range within a radius of $712 \mathrm{~m}$ [17] varying with bee species, bee's body size, and food availability [18], [19]. Stingless bee such as Heterotrigona itama prefers foraging plants closest to their hive especially from white- and cream-coloured flowers [20-22] with nectar containing high sugar concentration [19].

During foraging, forager bees collect nectar and store it in their honey stomach while their bodies are covered in pollen dust. Pollen profile collected by different stingless bees species has been documented in Southeast Asia [21-28] and South America [29-33]. Stingless bees collect pollen from underutilised fruits, tree, and ornamental plants, shrubs, epiphytes, herbs, and lianas [21,31]. They have smaller body size compared to honeybees, which provides an advantage in collecting pollen from small flowers such as Mimosa pudica [22,26] and Mimosa caesalpiniaefolia [33].

As the bees collect pollens, they use their salivary enzymes (amylase and glucosidase) [34] and honey [35] to moisten, agglutinate, and pack the pollen into "pollen basket" on their hind legs [36]. The addition of these substances converts flower pollen into bee pollen. The forager bees transport the collected pollen (bee pollen) with nectar back to their hive. Some beekeepers collect the bee pollen, and this is usually observed in the case of honeybee Apis. Bee pollen is acquired using a pollen trap installed at the hive entrance, which strips the pollen from the bee's leg by forcing the bees to crawl through a small tight hole [6]. 


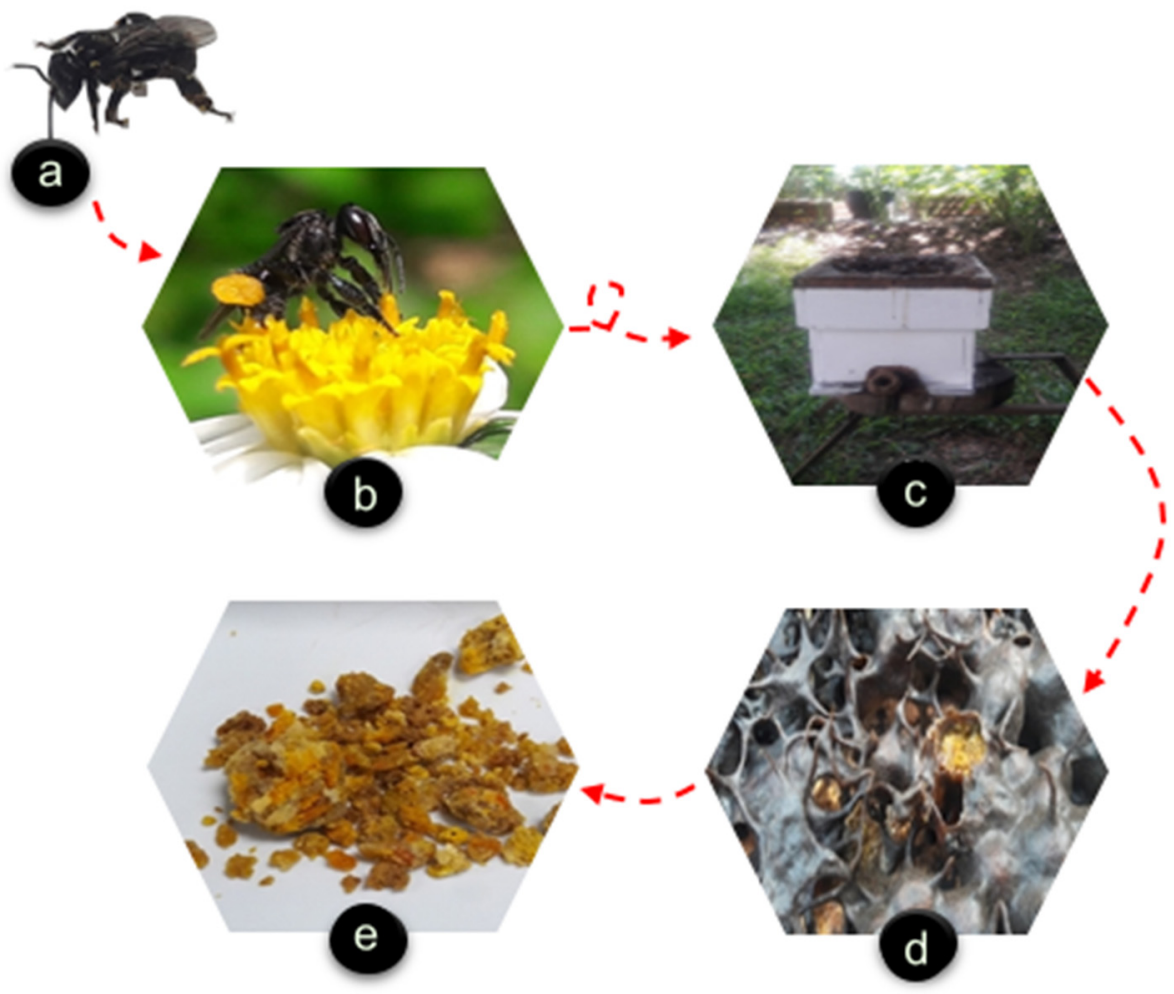

Figure 1. The production of bee bread from flower pollen. (a) Stingless bee, (b) stingless bee visits flower and collects pollen on its hind leg, (c) stingless bee returns to its hive, and (d) stores the pollen inside cerumen pots where lactic acid fermentation occurs to form bee bread. (e) Collected bee bread.

If the bee pollen is not harvested, the worker bees pack the bee pollen inside a cerumen pot (for stingless bee) (Figure 2) or honeycomb cells (for honeybee) made from beeswax and resin. Once the pollen pots are full, the pots are sealed closed [37] before being consumed by larvae or young adult bees as a protein source [2]. During storage, lactic acid fermentation takes place to transform bee pollen into bee bread [38].

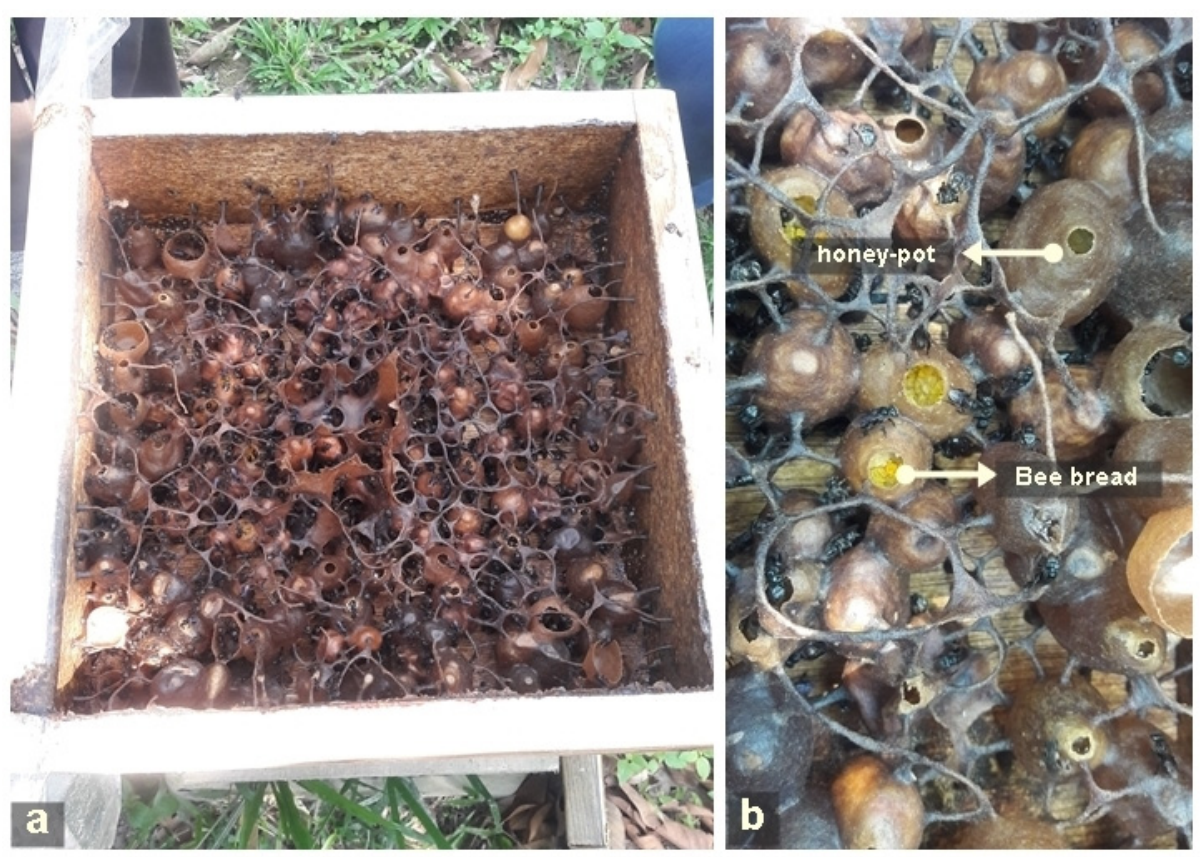

Figure 2. (a) Stingless bee colony and (b) honey and bee bread in separate cerumen pots. 
A single stingless bee colony could produce up to $6 \mathrm{~kg}$ of bee bread per year depending on the species. In Brazil, the maximum price for bee bread, locally known as "sambura" is 247 USD / kg [39]. In Malaysia, fresh wet bee bread could cost up to 95 USD/kg [22].

Because stingless bee's bee bread is stored in cerumen pot, its acquisition is different from those of honeybee. Honeybee bee bread is acquired either through manual extraction [40] or usage of a specialised bee bread harvester for large scale production [41]. However, the current method to acquire stingless bee's bee bread is using forceps, tweezers, or spatula. This imposes challenges especially towards mass production of bee bread for commercialisation [11].

\section{Biochemical Changes from Bee Pollen to Bee Bread}

Flower pollen undergoes different development stages to become the end product known as bee bread. The biochemical profiles of flower pollen, bee pollen, and bee bread (Figure 3) are different as several biochemical changes take places at each stage [11,42]. Early studies revealed minor differences between bee bread and bee pollen. Bee bread lacks starch and has low ash content but has higher reducing sugar and fibre than bee pollen [43]. In the last decade, a few studies have attempted to compare the nutrient content of bee pollen and bee bread using more advanced technology. Although Anđelković et al. [42] found higher crude ash, protein, fewer minerals, and lower cellulose in bee bread than bee pollen, the botanical origins of the pollens which could influence the outcomes were not investigated.

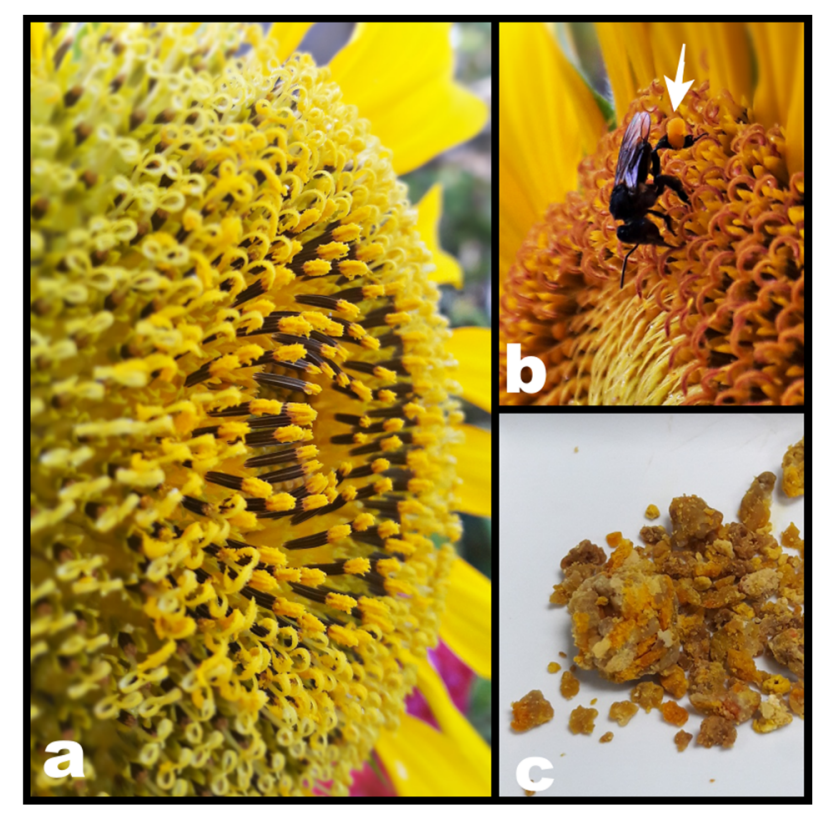

Figure 3. (a) Flower pollen, (b) bee pollen on the stingless bee (Heterotrigona itama) hind leg, and (c) fermented bee pollen (bee bread) collected from the stingless bee cerumen pot.

Comparing the chemical composition of monofloral pollens is more enticing [6]. For example, investigating and comparing the monofloral fresh pollen, bee pollen, and bee bread of Aloe greatheadii var. davyana and Helianthus anthuus (sunflower) showed that bee bread has significantly higher water and carbohydrate content, but lower protein, lipid, and fatty acid content than its fresh pollen [44,45]. Flower pollen chemical profile was assumed to shift after collection because of the addition of bee salivary enzymes and honey [43,45]. However, according to researchers, these changes are considered minor [44,45].

Perhaps the noticeable change between bee pollen and bee bread is the $\mathrm{pH}$. Bee bread is more acidic compared to bee pollen. Studies on $\mathrm{pH}$ changes of stingless bee pollen and bee bread are still lacking. However, when looking upon European bee pollen $\mathrm{pH}$, it shows to be significantly reduced from $\mathrm{pH} 4.7$ to 3.97 after transformation into bee bread [46]. 
Duarte et al. [47] also found high $\mathrm{pH}$ values (4.2-5.6) for Melipona asilvai, M. quadrifasciata anthidioides, M. scutellaris, M. subnitida, Tetragona clavipes, and Plebeia sp. bee pollen. The $\mathrm{pH}$ for stingless bee bee bread will be discussed in the later section.

Fermentation not only produces chemical changes in bee bread but also has been speculated to improve bee bread digestibility and bioavailability by degrading the outer pollen layer [48-50]. Nevertheless, Fernandes-da Silva [51] found no major difference in the nutritional value and digestibility between bee pollen and bee bread collected by Scaptotrigona postica. A recent study also showed bee bread digestibility equivalent to those of fresh pollen even after consumption and digestion by Apis mellifera scutellata [52]. In this sense, microbial fermentation was not able to ferment the highly resistant pollen walls to the fullest.

\section{Physicochemical Properties}

\subsection{Physical Properties}

A stingless bee can carry a pollen weight of $10.9 \mathrm{mg}$ [53] and the pollen load decreases as the size of the bee increases [54]. The honeybee is larger than a stingless bee; therefore, it only carries an average of $7.9 \mathrm{mg}$ pollen [55]. Pollen has diverse colours ranging from yellow, orange, brown, black, and purple which could indicate its botanical origin. For instance, bellflower (Nesocodon mauritianum) has purple pollen. Pollen colour tends to change into black once stored in hive due to oxidation [56]. Bee product's colour is also associated with their phenolic content. The pollen colour is attributed to the presence of flavonoid [57], which relatively depends on the plant source.

Pollen wall has three different layers. The outermost layer is the pollenkitt followed by the outer wall (exine) and inner wall (intine). The exine consists of sporopollenin, while the intine is composed of cellulose and pectin [58]. The exine is the most difficult layer to be digested by bees and animals [59], and the structural integrity remains after storage of bee bread in the hive [51,52].

Bee bread contains accumulated pollen grains from various flowering plants. Although analysis of pollen colour could give an insight into its floral origin, a single pollen colour does not indicate monofloral source [60]. This is confirmed by Modro et al. [56] who suggested accurate pollen analysis for taxa identification by melissopalynology.

Melissopalynology is the microscopic study of pollen grains in bee products such as honey, pollen, propolis, and royal jelly [61]. Pollen grains are studied based on their physical features such as size, shape, aperture, and ornamentation [58]. The pollen grains sizes can be between 2.5 and $250 \mu \mathrm{m}$ in diameter [10]. The surface of pollen has different structural properties such as clava, perforate, reticulate (mesh), granula, and echinate (spikelike) [58]. Each pollen is classified as either predominant, secondary dominant, or minor based on its frequency [62], which is subsequently important for product identification as either monofloral/unifloral or multifloral.

Pollen morphology is species-specific; therefore, it provides valuable information on the pollen's botanical origin and plants preferentially visited by the bees $[24,63]$. This helps beekeepers plan and manage suitable landscape for bee foraging. Identifying plant origin also contributes to a better understanding of bee's nutritional source, and bee products made from these plants, eventually, give commercial value to it [61].

The taste of bee bread is different across species. For example, Tetragonula angustula, Ptilotrigona and Frieseomelitta doederlini, and F. varia produce sweet bee bread, whereas Melipona and Scaptotrigona produce bitter bee bread [39,64]. To reduce the bee bread sourness, it is marketed mixed with honey or added in vitamins and juices [39].

\subsection{Chemical Properties}

Importantly, 250 different compounds comprise bee bread, and these are macro- and micronutrients, vitamins, amino acids, fatty acids, and phenolic compounds [65]. Bee bread has been dubbed as the "perfectly complete food" on various occasions because of its nutrient richness [66-68]. Bee pollens are consumed mainly as human food in Brazil 
and European countries such as Bulgaria, Poland, and Switzerland, and therefore, its physicochemical parameters and nutritional values have been standardised there [36] Campos et al. [36] have proposed a quality criterion for honeybee Apis mellifera pollen to be considered as an international standard. However, unlike bee pollen, bee bread standard has yet to be articulated. Due to this setback, researchers opt to compare the research data of stingless bee bee bread to the international standard of bee pollen Apis spp. [22].

It is challenging to generalise bee bread nutritional values. Several factors including botanical and geographical origin, climatic condition, soil type, beekeepers' activities, or storage treatments in commercial production $[69,70]$ contribute to these challenges. The chemical properties of bee bread from stingless bee worldwide are summarised in Table 1.

\subsubsection{Water Content, Water Activity, and $\mathrm{pH}$}

Bee bread has shown to possess high moisture content. It is attributed to the pollen's hygroscopic properties, which attracts water from the environment. Bee bread accumulates water from the surrounding and also through the addition of bee saliva and honey resulting in a sticky end product. Storage in closed pots prevents water loss from bee bread [71]. According to the bee pollen standard [36], the water content in pollen should not be more than $6-9 / 100 \mathrm{~g}$.

Because pollen is hygroscopic, bee bread requires adequate drying parameters to achieve the desired moisture content. Different preservation methods are utilised in the beekeeping industry to preserve bee bread. Oven drying has been proven to be the best method to preserve bee bread over frozen and refrigeration method based on the reduction in moisture content and microbial load [72].

Bee bread has water activity between 0.60 and 0.92 (Table 1) within the range of $A_{w}$ suitable for microbial colonisation, which is $0.60-1.00$. The preservation method such as drying until $\mathrm{A}_{\mathrm{w}}$ goes below this level and can help prolong the bee bread shelf life. High $A_{w}$ of fresh bee bread provides a favourable environment for the growth of beneficial bacteria, pathogenic bacteria, fungi, or mould $[15,73,74]$. This creates concern over the risk of occurrence of mycotoxins, which has been reported in pollen [75]. Therefore, $A_{w}$ parameter should be critically observed for quality control during storage.

As previously mentioned, bee bread is more acidic than bee pollen. Duarte et al.'s [47] study on seven species of stingless bee's bee pollen in Brazil revealed that the $\mathrm{pH}$ values were in the range of 4.9-5.9. As shown in Table 1, $\mathrm{pH}$ values for stingless bee bee bread were reported to be in the range of 3.28-4.13. The lowest recorded $\mathrm{pH}$ was in one sample of bee bread of Melipona scutellaris ( $\mathrm{pH}$ 3.28) [33]. The $\mathrm{pH}$ value dropped as the lactic acid content in bee bread becomes higher (3.06\%-3.20\%) than bee pollen (0.56\%) [76] suggesting a lactic acid fermentation by bacteria and yeast [14] However, the exact mechanism is still poorly understood. 
Table 1. Chemical analysis of bee bread from stingless bee across different geographical locations.

\begin{tabular}{|c|c|c|c|c|c|c|c|c|c|c|c|}
\hline Bee Species & Origin & Botanical Origin & Moisture (\%) & Ash (\%) & Total Lipid (\%) & Protein (\%) & $\begin{array}{c}\text { Crude Fibres } \\
\text { (\%) }\end{array}$ & $\begin{array}{c}\text { Total } \\
\text { Carbohydrate (\%) }\end{array}$ & $\begin{array}{c}\text { Water } \\
\text { Activity }\end{array}$ & $\mathrm{pH}$ & References \\
\hline Heterotrigona itama & Malaysia & ND & 8.10 & 1.70 & - & 47.4 & - & 55.1 & - & - & [77] \\
\hline Heterotrigona itama & Malaysia & ND & - & - & $2.17-4.80$ & $17.22-18.37$ & - & $32.74-58.73$ & - & - & [78] \\
\hline Heterotrigona itama & Malaysia & $\mathrm{ND}$ & 30.45 & 3.28 & 13.43 & 30.43 & - & 22.36 & - & - & [79] \\
\hline $\begin{array}{l}\text { Tetragonula laeviceps } \\
\text { Tetragonula testaceitarsis }\end{array}$ & \multirow{3}{*}{ Thailand } & \multirow{3}{*}{$\begin{array}{c}\text { Trema micrantha, Cocos nucifera } \\
\text { Cocos nucifera, Acacia sp. } \\
\text { Trema micrantha, Cocos nucifera, } \\
\text { Acacia sp } \\
\text { Tapirira sp. }\end{array}$} & $\begin{array}{l}16.1^{\mathrm{a}} \\
31.7^{\mathrm{a}}\end{array}$ & $\begin{array}{l}2.30^{\mathrm{a}} \\
2.20^{\mathrm{a}}\end{array}$ & $\begin{array}{l}7.4^{\mathrm{a}} \\
5.4^{\mathrm{a}}\end{array}$ & $\begin{array}{l}15.5^{\mathrm{a}} \\
17.9^{\mathrm{a}}\end{array}$ & - & $\begin{array}{l}58.7^{\mathrm{a}} \\
43.1^{\mathrm{a}}\end{array}$ & - & - & \multirow{3}{*}{ [80] } \\
\hline Lepidotrigona terminata & & & $25.3^{\mathrm{a}}$ & $1.80^{\mathrm{a}}$ & $5.3^{\mathrm{a}}$ & $14.3^{\mathrm{a}}$ & - & $53.4^{\mathrm{a}}$ & - & - & \\
\hline Lepidotrigona flavibasis & & & $22.8^{\mathrm{a}}$ & $2.20^{\mathrm{a}}$ & $4.9^{\mathrm{a}}$ & $16.7^{\mathrm{a}}$ & - & $53.3^{\mathrm{a}}$ & - & - & \\
\hline Melipona sp. aff. eburnea & \multirow{2}{*}{ Venezuela } & \multirow{2}{*}{$\begin{array}{c}\text { Fabaceae Papilionoideae (46\%), } \\
\text { Malpighiaceae (26\%) } \\
\text { Malpighiaceae (54\%), Fabaceae } \\
\text { Papilionoideae (20\%), }\end{array}$} & 48.54 & 2.33 & 3.19 & 18.32 & - & 27.62 & - & - & \multirow{2}{*}{ [81] } \\
\hline $\begin{array}{l}\text { Scaptotrigona sp. } \\
\text { f. ochrotricha }\end{array}$ & & & 43.49 & 1.94 & 6.72 & 16.80 & - & 31.03 & - & - & \\
\hline $\begin{array}{l}\text { Meliponini seminigra } \\
\text { Meliponini interrupta }\end{array}$ & Brazil & $\begin{array}{l}\text { ND } \\
\text { ND }\end{array}$ & $\begin{array}{l}53.39 \\
37.12\end{array}$ & $\begin{array}{l}4.03^{\mathrm{a}} \\
2.74^{\mathrm{a}}\end{array}$ & $\begin{array}{c}10.81^{\mathrm{a}} \\
6.47^{\mathrm{a}}\end{array}$ & $\begin{array}{l}37.63^{\mathrm{a}} \\
25.00^{\mathrm{a}}\end{array}$ & $\begin{array}{r}9.30^{\mathrm{a}} \\
13.65^{\mathrm{a}}\end{array}$ & $\begin{array}{l}25.66^{\mathrm{a}} \\
44.27^{\mathrm{a}}\end{array}$ & $\begin{array}{l}0.91 \\
0.85\end{array}$ & $\begin{array}{l}3.70 \\
3.34\end{array}$ & [82] \\
\hline Tetragonula angustula & Venezuela & ND & $23.56-25.45$ & $1.90-2.22$ & $3.98-5.43$ & $18.10-26.31$ & - & $42.25-49.4$ & - & - & [84] \\
\hline Frieseomelitta sp. aff. Varia & \multirow{7}{*}{$\begin{array}{l}\text { Southern } \\
\text { Venezuela }\end{array}$} & \multirow{7}{*}{$\begin{array}{l}\text { Antigonon sp., Astronium sp., } \\
\text { Avicennia sp., Bidens sp., Eupatorium } \\
\text { sp., Scrophularia nodosa } \\
\text { Solanum americanum }\end{array}$} & 29.96 & 3.13 & 3.51 & 24.72 & - & 38.68 & - & - & \multirow{7}{*}{ [9] } \\
\hline Melipona compressipes & & & 32.75 & 2.85 & 4.12 & 21.01 & - & 39.27 & - & - & \\
\hline Melipona eburnean & & & 35.89 & 2.54 & 6.03 & 18.44 & - & 37.10 & - & - & \\
\hline Mélipona favosa & & & 29.01 & 2.92 & 4.38 & 22.31 & - & 41.38 & - & - & \\
\hline Melipona sp. fulva & & & 31.65 & 2.45 & 5.72 & 19.43 & - & 40.75 & - & - & \\
\hline $\begin{array}{l}\text { Melipona lateralis } \\
\text { kangarumensis }\end{array}$ & & & 38.32 & 2.76 & 4.80 & 21.77 & - & 32.35 & - & - & \\
\hline Melipona paraensis & & & 42.74 & 1.93 & 5.23 & 19.08 & - & 31.02 & - & - & \\
\hline Melipona mandacaia & Brazil & ND & 36.0 & 4.9 & - & 21.0 & 3.6 & - & 0.86 & 3.49 & [85] \\
\hline Scaptotrigona mexicana & $\begin{array}{l}\text { Cañada Blanca, } \\
\text { Mexico }\end{array}$ & $\begin{array}{l}\text { Heliocarpus sp., Bursera simaruba, } \\
\text { Chamaecrista sp., Desmodium } \\
\text { adscendens, Desmodium tortuosum, } \\
\text { Eugenia capuli, Bidens pilosa, } \\
\text { Vernonia sp., Pouteria sp., Verbesina } \\
\text { sp., Coccoloba sp. }\end{array}$ & 24.6 & 3.1 & 0.46 & 22.01 & - & 31.99 & - & 3.46 & {$[86]$} \\
\hline
\end{tabular}


Table 1. Cont.

\begin{tabular}{|c|c|c|c|c|c|c|c|c|c|c|c|}
\hline Bee Species & Origin & Botanical Origin & Moisture (\%) & Ash (\%) & Total Lipid (\%) & Protein (\%) & $\begin{array}{c}\text { Crude Fibres } \\
(\%)\end{array}$ & $\begin{array}{c}\text { Total } \\
\text { Carbohydrate (\%) }\end{array}$ & $\begin{array}{c}\text { Water } \\
\text { Activity }\end{array}$ & $\mathrm{pH}$ & References \\
\hline Scaptotrigona mexicana & $\begin{array}{l}\text { Manuel León, } \\
\text { Mexico }\end{array}$ & $\begin{array}{l}\text { Bursera simaruba, Parthenium } \\
\text { fruticosum, Helianthus sp., Spondias } \\
\text { mombin, Solanum sp., Chamaecrista } \\
\text { sp., Serjania sp., Heliocarpus sp., } \\
\text { Vernonia sp., Pithecellobium sp. } \\
\text { Coccoloba sp., Bidens pilosa. }\end{array}$ & 15.5 & 2.5 & 1.1 & 20.49 & - & 33.10 & - & 3.61 & [86] \\
\hline Scaptotrigona mexicana & $\begin{array}{l}\text { Fortín de las } \\
\text { Flores, Mexico }\end{array}$ & $\begin{array}{l}\text { Spondias mombin, Dendropanax } \\
\text { arboreus, Solanum sp., Verbesina sp., } \\
\text { Heliocarpus sp., Pouteria sp., Cordia } \\
\text { sp., Vernonia sp., Eugenia sp., } \\
\text { Dysphania ambrosioides, }\end{array}$ & 26.7 & 2.9 & 1.1 & 21.06 & - & 35.02 & - & 3.64 & [86] \\
\hline Melipona scutellaris & Brazil & $\begin{array}{l}\text { Tapirira guianensis, Spondias mombin, } \\
\text { Syagrus sp., Hylocereus undatus, } \\
\text { Pueraria hhaseoloides, Mimosa } \\
\text { caesalpiniifolia, Pithecellobium dulce, } \\
\text { Ossaea sp., Miconia sp., Psidium sp., } \\
\text { Corymbia torrelliana, Myrcia obovate, } \\
\text { Syzygium samarangense, } \\
\text { Campomanesia sp., Eugenia stipitate, } \\
\text { Eugenia uniflora, Plinia cauliflora, } \\
\text { Solanum macrocarpon, Solanum } \\
\text { stipulaceum, Solanum sp., Cestrum } \\
\text { sp., Allophylus sp. }\end{array}$ & 44.71 & 1.84 & 4.25 & 23.88 & 0.87 & 24.48 & 0.92 & 3.75 & [71] \\
\hline
\end{tabular}




\subsubsection{Carbohydrates}

Table 1 summarises the carbohydrate content in the stingless bee bee bread, which ranges from $10.85 \%$ to $59.94 \%$. Carbohydrates mostly make up bee bread due to the addition of nectar during processing of pollen into bee bread. A significant increase in carbohydrates has been reported in two separate studies on monofloral bee bread [44,45]. The authors found higher carbohydrate content in Aloe greatheadii var. davyana and Helianthus annuus bee bread in comparison to its fresh pollen.

Most bee bread from Southeast Asia (SEA) is reported to have higher carbohydrate values than bee bread from other regions. Thailand's Tetragonula testaceitarsis bee bread had the lowest value with $43.1 \%$ [80], while Tetragonula biroi Friese from the Philippines has the highest value with 59.94\% [83] among SEA countries.

The sugar analysis comparison (Table 2) shows reducing sugars such as fructose, glucose, and sucrose were present in high amounts. Mannitol (sugar alcohol) was also found abundant in bee bread of Tetragonula biroi from the Philippines [83], Meliponini subnitida from Brazil [29,87], and Trigona spp. from Malaysia [88]. Other oligosaccharides such as sorbitol, cellobiose, isomaltose, maltose, raffinose, and stachyose were found in minute amount in Tetragonula biroi bee bread [83].

Bee incorporates nectar and its salivary enzymes during pollen agglutination [10]. Depending on bee species, honeybee Apis mellifera L. salivary (thoracic) gland secretes invertase, amylase, and glucosidase [89]. Stingless bee Meliponini, Trigonini, and Scaptotrigona spp. could digest pollen polysaccharides into simple sugar using enzymes $\alpha$ and $\beta$-amylase and $\alpha$-glucosidase [34]. Simple sugars are hypothesised to be fermented by bacteria during bee bread fermentation resulting in varying degrees of sugar fractions.

\subsubsection{Protein}

Bee bread is rich in protein content, thus becoming the main protein source for bee development. The protein levels are varied across different geographical locations and between bee species (10.19-47.4\%) (Table 1). Pollen with highest protein content was found to have originated from a highly nectariferous plant [90]. Although protein content decreases from fresh pollen to bee bread [44,45], whereas the amino acid concentration remains unchanged in fresh pollen, bee pollen, and bee bread [44,45].

Bee bread is claimed to contain all the essential amino acids-amino acids that cannot be synthesised by an organism $[67,69,70]$, and it is indeed what was observed in the bee bread of stingless bee (Table 1). Belina-aldemita et al. [83] quantified the total free amino acids in Tetragonula biroi from the Philippines and found mean values of only $1.83 \mathrm{~g} / 100 \mathrm{~g}$ bee bread. Among the essential amino acids, leucine, and phenylalanine were highly present in the studied bee bread (Table 3).

\subsubsection{Lipid}

Lipid content of stingless bee bee bread is between $0.46 \%$ and $14.43 \%$ (Table 1 ). The outer pollen wall (pollenkitt) is made up of lipid [59,91]. Lipid is also present in the pollen grain at a different amount between the same and different species [92]. Bee bread lipid content is similar to bee pollen but significantly lower than flower pollen [45]. Addition of bee glandular enzymes into fresh pollen could alter the lipid composition available in bee pollen and bee bread.

Bee bread has diverse fatty acid profiles, which provides benefits to the bee nutrition and also for human health. According to Szczesna [93], the most abundant fatty acids in bee pollen are linoleic (omega-6) followed by $\alpha$-linolenic (omega-3) and palmitic acids. The fatty acid composition is not much different between bee pollen and bee bread [44]. Bee bread is rich in polyunsaturated fatty acids (PUFAs) such as omega-3, fatty acids which cannot be synthesised by our body [94]. Studies on fatty acid composition in stingless bee bee bread is still limited. For instance, bee bread of Melipona scutellaris contains 12 fatty acids ( 9 saturated and 3 unsaturated), and the most abundant saturated fatty acid was 
capric acid (1.89-5.66 g/100 g) and the common PUFAs were Omega-6 ( $\alpha$-linoleic acid) (0.50-1.63 g/100 g) and omega-3 (0.30-0.86 g/100 g) [33].

However, in another study, palmitic acid $(1.65 \mathrm{~g} / 100 \mathrm{~g})$ was the prevalent fatty acid followed by omega-6 (1.52 g/100 g) in Tetragonula laeviceps bee bread. The ratio of polyunsaturated to saturated fatty acids was 1.59 , higher than the ideal ratio of 1 , which can slightly reduce HDL cholesterol level [80]. Similarly, palmitic acid was the dominant fatty acid among 15 fatty acids identified in Melipona mandacaia bee bread [85]. Omar et al. [88] analysed the volatile compounds in Malaysia trigona species using gas chromatography (GC-MS). Propanoic acid and palmitic acid were the most abundant saturated fatty acids in Trigona apicalis $(4.04 \%)$ and Trigona thoracica $(1.28 \%)$ bee bread, respectively. Meanwhile, minute amounts of omega- 3 and omega- 6 fatty acids were detected in range of $(0.07-0.11 \%)$. In addition, analysis of volatile organic compounds (VOCs) found acetic acid as the sole organic acid in Australian Tetragonula carbonaria and Tetragonula hockingsi but absent in Austroplebeia australis [95].

\subsubsection{Phenolic Compounds}

Phenolic compounds are secondary plant metabolites found widely in plants as a protective mechanism when encountering biotic or abiotic stress. They include phenolic acids, flavonoids, proanthocyanidins, and more. Intake of food containing phenolic compounds is sought to reduce the risk of gaining chronic diseases because of its antioxidant and anti-inflammatory properties [96]. According to findings of Urcan et al. [97], bee pollen and bee bread have similar phenolic profile. In contrast, Kaškonienè et al. [98] revealed that there is increase in flavonoid content (55-135\%) after bee bread fermentation. Several studies have quantified the total phenolic content (TPC) and total flavonoid content (TFC) in stingless bee bee bread.

TPC and TFC content varies for different stingless bee species even from the same location [99]. The solvent of extraction also influences extraction efficiency. For instance, ethanolic extract and aqueous extract of Heterotrigona itama bee bread yielded different amounts of polyphenols. Ethanolic extracts were found to have higher TPC (21.32-22.54 $\mathrm{mg}$ GAE/g) and TFC (16.48-26.57 $\mathrm{mg} \mathrm{QE/g)} \mathrm{than} \mathrm{aqueous} \mathrm{extract} \mathrm{[78].} \mathrm{When} \mathrm{comparing}$ between ethanol and methanol, both solvents showed similar efficiency in extracting phenolic compounds from Australian Austroplebeia spp. and Tetragonula spp. bee bread. [100]. However, TPC and TFC of ethanolic extracts were slightly higher with $1281.2-2683.2 \mathrm{mg}$ GAE/100 g pot-pollen and 282.9-698.0 mg QE/100 g pot-pollen, respectively. By far, ethanol has shown superior extraction for stingless bee bee bread compared to other solvents tested.

In Southern Venezuela, Vit et al. [84] determined the phenolic content and flavonoid contents in ethanolic extract of Tetragonula angustula bee bread. TPC ranged from 1053.1 to $2627.4 \mathrm{mg}$ GAE/100 g pot-pollen, while the TFC was between 104.6 and $676.4 \mathrm{mg}$ QE/100 g pot-pollen. In another study, Vit et al. [9] detected lower TPC and TFC from bee bread of seven stingless species of Frieseomelitta sp. and Melipona spp. with 1018.0-2085.0 mg GAE/100 g pot-pollen and 75.7-656.3 mg QE/100 g pot-pollen, respectively.

Table 4 summarises the bioactive compounds available in stingless bee bee bread. Figure 4 shows the chemical structures of the bioactive compounds. In general, kaempferol, isorhamnetin, and quercetin were the most frequently detected compounds in bee bread of stingless bee $[9,29,78,101]$. These molecules are also widely found in bee pollen of Apis spp. [4], fruits and vegetables, with great potential to reduce the risks of cancer [102,103]. 
Table 2. Essential amino acid in stingless bee bee bread $(\mathrm{g} / 100 \mathrm{~g})$.

\begin{tabular}{|c|c|c|c|c|c|c|c|c|c|c|c|c|}
\hline Bee Species & Country & Instrument & Phe & Val & His & Met & Iso & Leu & Thr & Ala & Try & References \\
\hline Heterotrigona itama & Malaysia $^{1}$ & HPLC & $1.84-2.80$ & $1.00-1.18$ & $0.78-1.15$ & $0.37-0.53$ & $0.76-0.83$ & $1.61-1.83$ & $1.52-2.00$ & $1.00-1.06$ & ND & {$[22]$} \\
\hline Tetragonula laeviceps & Philippines $^{1}$ & MS-GC & 1.63 & 0.65 & 0.96 & 0.12 & 0.88 & 1.62 & 0.17 & 0.40 & 0.96 & [80] \\
\hline Melipona subnitida & Brazil $^{2}$ & HPLC-PDA & $0.36-0.41$ & $0.29-0.41$ & $0.70-0.73$ & $0.14-0.17$ & $0.14-0.21$ & 0.61 & $0.23-0.30$ & $0.91-0.93$ & $0.70-0.73$ & [87] \\
\hline
\end{tabular}

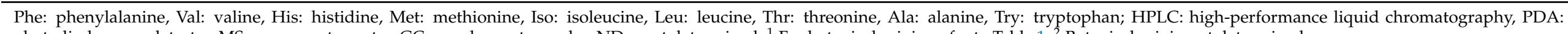
photodiode-array detector, MS: mass spectrometry, GC: gas chromatography; ND = not determined; ${ }^{1}$ For botanical origin, refer to Table $1 ;{ }^{2}$ Botanical origin not determined.

Table 3. Sugar content in stingless bee bee bread (g/100 g).

\begin{tabular}{|c|c|c|c|c|c|c|c|c|c|}
\hline Bee Species & Country & Botanical Origin & Instrument & Glucose & Fructose & Sucrose & Maltose & Mannitol & References \\
\hline Heterotrigona itama & Malaysia & $\begin{array}{l}\text { Mimosa pudica, Sphagneticola trilobata, Bidens } \\
\text { pilosa, Cassia sp., Areca catechu, Peltophorum } \\
\text { pterocarpum, Phaleria capitate, Cassia siamea, } \\
\text { Citrus aurantifolia Ageratum conyzoides }\end{array}$ & HPLC-ELSD & $10.27-12.40$ & $0.40-1.49$ & $0.60-2.10$ & $0.70-2.00$ & - & [22] \\
\hline Melipona subnitida & Brazil & ND & HPLC-RID & - & - & - & - & $20.80-31.00$ & [87] \\
\hline Melipona subnitida & Brazil & $\begin{array}{l}\text { Mimosa gemmulata, Mimosa verrucada, Fabaceae, } \\
\text { Scrophulariaceae (species not identified) }\end{array}$ & $\begin{array}{l}\text { Column } \\
\text { chromatography- } \\
\text { TLC-UV }\end{array}$ & - & - & - & - & 34.90 & [101] \\
\hline
\end{tabular}

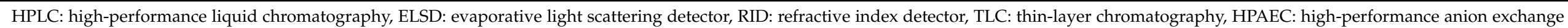
chromatography, PAD: pulsed amperometric detector.

Table 4. Bioactive compounds in stingless bee bee bread.

\begin{tabular}{|c|c|c|c|c|c|}
\hline Bee Species & Origin & Botanical Origin & Instrument & Compound & References \\
\hline Melipona subnitida & Brazil & $\begin{array}{l}\text { Mimosa gemmulata, Mimosa verrucada, Fabaceae, } \\
\text { Scrophulariaceae (species not identified) }\end{array}$ & Column chromatography & $\begin{array}{l}\text { 6-naringenin, 7-isorhamnetin, 2-tricetin, 3-selagin, } \\
\text { 4-8-methoxyherbacetin }\end{array}$ & [101] \\
\hline Heterotrigona itama & Malaysia & ND & LC-MS & $\begin{array}{l}\text { Caffeic acid, ferulic acid, kaempferol, apigenin, } \\
\text { and isorhamnetin }\end{array}$ & [104] \\
\hline $\begin{array}{l}\text { Frieseomelitta sp. aff. Varia, } \\
\text { Melipona compressipes, } \\
\text { Melipona eburnean } \\
\text { Melipona favosa, } \\
\text { Melipona sp. fulva } \\
\text { Melipona lateralis kangarumensis } \\
\text { Melipona paraensis }\end{array}$ & Southern Venezuela & $\begin{array}{c}\text { Antigonon sp., Astronium sp., Avicennia sp., Bidens sp., } \\
\text { Eupatorium sp., Scrophularia nodosa } \\
\text { Solanum americanum }\end{array}$ & HPLC-UV & $\begin{array}{c}\text { Kaempferol, luteolin, quercetin } \\
\text { Kaempferol, luteolin, 8 methoxykaempferol } \\
\text { Genkwanin, 8 methoxykaempferol } \\
\text { Quercetin } \\
\text { Kaempferol, 8 methoxykaempferol, quercetin } \\
\text { Kaempferol, luteolin, 8 methoxykaempferol, quercetin } \\
\text { Genkwanin, luteolin }\end{array}$ & [9] \\
\hline
\end{tabular}


Table 4. Cont.

\begin{tabular}{|c|c|c|c|c|c|}
\hline Bee Species & Origin & Botanical Origin & Instrument & Compound & References \\
\hline Melipona rufiventris & Brazil & ND & Column chromatography—NMR & $\begin{array}{c}p \text {-hydroxycinnamic acid, dihydroquercetin, } \\
\text { isorhamnetin, isorhamnetin-3-O-(6"-O-E- }- \text {-coumaroyl)- } \\
\beta-D \text {-glucopyranoside, luteolin, } \\
\text { and quercetin }\end{array}$ & [29] \\
\hline Scaptotrigona affinis postica & Brazil & ND & LC-ESI-IT-MS/MS & $\begin{array}{c}\text { Gluconic acid, digalloylshikimic acid, } \\
\text { quercetin-3,4-diglucoside, apigenin-6-C-glucoside, } \\
\text { isoorientin-2"-O-rhamnoside, kaempferol } \\
\text { 3,7-di-O-rhamnoside, ellagic acid, monogalloylglucose, } \\
\text { protocatechuic acid 3-glucoside, procyanidin dimmer } \\
\text { digallate (a-type) }\end{array}$ & [105] \\
\hline Tetragonula biroi Friese & Philippines & ND & HPLC-DAD & Rutin, quercetin-3-O- $\beta$-D-glucoside, and quercetin & [107] \\
\hline
\end{tabular}

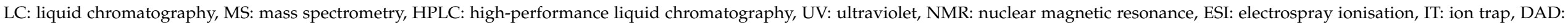
photodiode array detection. 
<smiles>COc1cc(/C=C/C(O)O)ccc1O</smiles><smiles>Oc1ccc(/C=C/C(O)O)cc1O</smiles><smiles>O=C(O)CCc1ccc(O)cc1</smiles><smiles>O=c1cc(-c2ccc(O)cc2)oc2cc(O)cc(O)c12</smiles>

Apigenin<smiles>O=c1cc(-c2ccc(O)c(O)c2)oc2cc(O)cc(O)c12</smiles>

Luteolin<smiles></smiles>

Naringenin<smiles>O=c1c(O)c(-c2ccc(O)c(O)c2)oc2cc(O)cc(O)c12</smiles>

Quercetin<smiles>COc1cc(O)c2c(=O)cc(-c3ccc(O)cc3)oc2c1</smiles>

Genkwanin<smiles>COc1cc(-c2cc(=O)c3c(O)cc(O)cc3o2)cc(O)c1O</smiles>

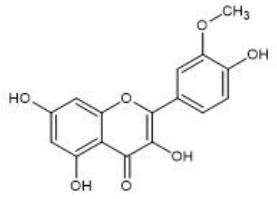

Isorhamnetin<smiles>Cc1ccc(C2Oc3cc(O)cc(O)c3C(=O)C2O)cc1</smiles>

Kaempferol<smiles>Oc1cc(O)c2c(c1)OC(c1cc(O)c(O)c(O)c1)=CC2O</smiles><smiles>O=c1c(O)c(-c2ccc(O)cc2)oc2c(O)c(O)cc(O)c12</smiles>

Figure 4. Chemical structures of some of the phenolic compounds found in stingless bee bee bread.

\subsubsection{Other Micronutrients}

Analysis of bee bread vitamin content is still scarce. Heterotrigona itama bee bread contains an average of $0.1108 \mathrm{mg}$ vitamin $\mathrm{C} / \mathrm{g}$ bee bread, which is considerably low based on the daily recommended intake [22]. Because vitamin $C$ is unstable, some factors such as the method of preservation, drying parameter, and storage age and condition need to be optimised as they have shown to affect the vitamin content in pollen $[60,108]$. External factors, for instance, botanical origin, soil type, and climate are also suggested to influence vitamin C in pollen [109].

The most abundant mineral in stingless bee bee bread is potassium followed by phosphorus. From the studies conducted (Table 5), potassium was in the range of 2222.5$13,366.6 \mathrm{mg} / \mathrm{kg}$. Similarly, it is also the most prevalent mineral in stingless bee honey [110]. Other minerals such as boron, rubidium, and strontium have been found in trace amounts in bee bread of Tetragonula biroi [83].

Apart from minerals, toxic metals such as arsenic, mercury, lead, and cadmium were detected in bee bread of Heterotrigona itama [22] and with a few H. itama samples exceeding the proposed limit for heavy metal [36]. Belina-aldemita et al. also detected these inorganic contaminants in Tetragonula biroi Friese bee bread but at a safe level [74]. Toxic metals accumulation in bee bread imposes high risk to human health but it can also become a good bioindicator of metal pollution in the environment [111] as a result of anthropogenic activities in nearby areas. 
Table 5. Mineral composition in stingless bee bee bread.

\begin{tabular}{|c|c|c|c|c|c|c|c|c|c|c|c|c|c|}
\hline Bee Species & Country & Instrument & K & $\mathbf{P}$ & $\mathrm{Na}$ & $\mathrm{Mg}$ & $\mathrm{Ca}$ & Mn & $\mathrm{Fe}$ & $\mathrm{Cu}$ & $\mathrm{Zn}$ & Se & References \\
\hline Heterotrigona itama & Malaysia & ICP-MS & 6524.9 & 6402.28 & 139.70 & 1635.4 & 1547.31 & 61.66 & 126.43 & 12.7671 & 60.62 & 0.26 & [22] \\
\hline Tetragonula laeviceps & & & 5656.0 & - & 89.9 & 1160.0 & 2566.0 & - & - & - & - & - & \multirow{3}{*}{ [80] } \\
\hline Tetragonula testaceitarsis & & ICP-OES & 4594.7 & - & 133.5 & 1318.0 & 2904.0 & - & - & - & - & - & \\
\hline $\begin{array}{l}\text { Lepidotrigona terminata } \\
\text { Lepidotrigona flavibasis }\end{array}$ & Brazil & ICP-OES & $\begin{array}{l}4606.3 \\
5125.7\end{array}$ & - & $\begin{array}{l}77.2 \\
81.7\end{array}$ & $\begin{array}{l}1176.0 \\
1315.3\end{array}$ & $\begin{array}{l}2507.3 \\
2719.7\end{array}$ & - & - & - & - & - & \\
\hline Melipona subnitida & Brazil & FAAS & 5918.5-13,366.6 & - & - & $975.4-2166.1$ & $1864.1-3424.9$ & $35.1-75.0$ & $16.4-33.5$ & $0.8-1.9$ & $36.4-71.2$ & - & [87] \\
\hline Scaptotrigona mexicana & Mexico & ICP-OES & $2222.5-2836.9$ & $2736.1-3657.3$ & - & - & - & - & - & - & - & - & [86] \\
\hline Tetragonula biroi & Philippines & ICP-MS & - & - & - & $1763.58-2407.65$ & $3780.28-5186.89$ & $42.58-266.90$ & $70.37-123.77$ & $9.52-12.02$ & $45.16-56.25$ & - & [83] \\
\hline
\end{tabular}

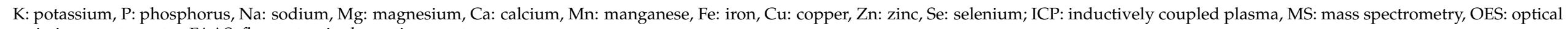
emission spectrometry, FAAS: flame atomic absorption spectrometry. 


\section{Health Benefits}

There has been a tremendous report published on bee pollen as it is shown to possess therapeutic properties such as antioxidant, anti-inflammatory, antibacterial, anti-fungicidal, hepatoprotective, and anti-atherosclerotic activities [10]. In contrast, only a few publications have been reported on stingless bee bee bread's biological properties, which are shown in Table 6.

\subsection{Antimicrobial Properties}

Bee bread extract contains phenolic compounds, which can be attributed to its antimicrobial properties. Therefore, its importance as an antimicrobial agent has to be acknowledged not only towards bacteria but also towards yeast and parasite. Carneiro et al. [112] demonstrated that bee bread extracts of stingless bee $M$. compressipes manaosensis inhibited $P$. aeruginosa, M. smegmatis, and Candida albicans efficiently and also mosquito larva C. quinquefasciatus, a vector for human parasitic worm Wuchereria bancrofti, in a concentration-dependent manner.

Akhir et al. [113] used ethanolic extract and hexanoic extract of Heterotrigona itama bee bread against Bacillus cereus, Staphylococcus aureus, Escherichia coli, and Salmonella sp. Grampositive bacteria were more sensitive towards the bee bread extracts, whereas ethanolic extract demonstrated stronger antibacterial activity compared to hexane extract.

Meanwhile, Perez-Perez et al. [100] examined the antibacterial activities of ethanolic and methanolic extract from bee bread of Austroplebeia australis, Tetragonula carbonaria, and Tetragonula hockingsi in Australia. The extracts were effective against both Gram-positive (Staphylococcus aureus, Bacillus subtilis) and Gram-negative bacteria (Enterobacter cloacae, Escherichia coli, and Pseudomonas aeruginosa). Similarly, extraction using ethanol showed better results as shown by the lowest minimum inhibitory concentration recorded by ethanolic extracts of Tetragonula hockingsi bee bread.

Sulbarán-Mora et al. [114] investigated bee bread ethanolic extracts of Frieseomelitta, Melipona, and Tetragonisca spp. from Venezuela and found that they exhibited antibacterial effects against Bacillus subtilis, Staphylococcus aureus, Enterobacter cloacae, and Pseudomonas aeruginosa but not against Escherichia coli. The antibacterial activities were correlated to the phenolic content.

\subsection{Antioxidant Properties}

Phenolic compounds are one the most important natural antioxidants, which can be found in fruits, vegetables, tea, herbs, and essential oils. Antioxidant removes overproduced free radicals or reactive oxygen species (ROS), which cause molecular damages on DNA, protein, and lipid. Consequently, it has been linked with onset of diseases such as cancer and inflammation [115]. Stingless bee bee bread contains antioxidant compounds such as phenolic compounds and vitamin C [22]. Therefore, it has been explored for its ability to remove free radicals. Its antioxidant activity using in vitro study has been documented in Malaysia [79,99,113], Brazil [47,105,106], Venezuela [9,84], and Australia [100].

There are multiple methods to assess the antioxidant activity of a plant extract and 2,2,-di-phenyl-2-picryl-hydrazyl (DPPH) is the most common in vitro method applied due to its simplicity, cost effectiveness, and rapidity [116]. However, assessing using more than two in vitro models is more preferable because of the complexity of phytochemicals [117]. Therefore, bee bread antioxidant activity is assessed based on DPPH activity coupled with other antioxidant assays (Table 6).

Antioxidant activity is also affected by solvent extraction. For example, the antioxidant activities of ethanolic extract from $H$. itama bee bread were determined using DPPH and 2,2-azinobis-(3-ethylbenzothiazoline-6-sulphonic acid) (ABTS) [113]. The ethanolic extract showed higher DPPH and FRAP radical scavenging activity $(93.60 \pm 0.03 \%$ and $97.95 \pm 0.01 \%$. respectively) in comparison to hexanoic extract. 
Table 6. Health benefits of stingless bee bee bread.

Stingless Bee Species

Origin

Sample Preparation

Antimicrobial Activity

Bee bread from 3 sampling sites was extracted using hexane (Hex), EtOH

$$
\text { and } \mathrm{MetOH}
$$

Agar well diffusion and MIC

Maues, Amazonas, Brazil
Bee bread was extracted in hexane and $70 \% \mathrm{EtOH}$

Australia

Extraction in $\mathrm{MetOH}$ and EtOH

Agar well diffusion and MIC

Austroplebeia australis,

Tetragonula hockingsi

Frieseomelitta sp. aff. Varia,

Melipona compressipes,

Melipona eburnean, Melipona favosa

\begin{tabular}{|c|c|c|c|}
\hline & \multicolumn{3}{|c|}{ Antioxidant Activity } \\
\hline Heterotrigona itama & Malaysia & Extraction in $95 \% \mathrm{EtOH}$ & DPPH \\
\hline $\begin{array}{c}\text { Trigona apicalis, Trigona itama, } \\
\text { Trigona thoracica }\end{array}$ & Malaysia & Extraction in MetOH & DPPH \\
\hline Heterotrigona itama & Malaysia & $\begin{array}{c}\text { Bee bread was extracted in hexane } \\
\text { and } 70 \% \mathrm{EtOH} \text { at concentration } \\
150 \mu \mathrm{L} / \mathrm{mL}\end{array}$ & DPPH and ABTS \\
\hline $\begin{array}{c}\text { Melipona asilvai } \text { Moure, } \\
\text { M. quadrifasciata anthidioides } \\
\text { Lepeletier, M. scutellaris Latreille, } \\
\text { M. subnitida Ducke, } \\
\text { Frieseomelitta varia Lepeletier, } \\
\text { Tetragona clavipes Fabricius and } \\
\text { Plebeia sp. }\end{array}$ & Brazil & $\begin{array}{l}\text { Extraction in } 70 \% \text { EtOH at } \\
\text { concentration } 50 \mathrm{mg} / \mathrm{mL}\end{array}$ & $\begin{array}{l}\text { DPPH, FRAP and inhibition } \\
\text { of } \beta \text {-carotene }\end{array}$ \\
\hline $\begin{array}{l}\text { Frieseomelitta sp. aff. Varia, } \\
\text { Melipona compressipes, } \\
\text { Melipona eburnean, Melipona favosa, } \\
\text { Melipona sp. fulva, Melipona lateralis } \\
\text { kangarumensis, Melipona paraensis }\end{array}$ & Brazil & Extraction in $95 \% \mathrm{EtOH}$ & $\begin{array}{l}\text { ABTS, Fenton type reaction, and } \\
\text { hydroxyl radical }\end{array}$ \\
\hline
\end{tabular}

kangarumensis, Melipona paraensis
All sample inhibited Mycobacterium smegmatis (ATCC 607) and Pseudomonas aeruginosa (ATCC 27853). Only bee bread hex, EtOH, and 10557). C. albicans was Maues 3 inhibited Streptococcus oralis (ATCC 1ed showed MIC greater than $1000 \mathrm{\mu g} / \mathrm{mL}$ Bee bread EtOH Maurs 1 and MetOH Maues 3 showed larvicidal activity C. quinquefasciatus

$$
\mathrm{LC}_{50} 218.2 \text { and } 228.8 \mu \mathrm{g} / \mathrm{mL}
$$

Gram-positive bacteria (B. cereus and S. aureus) showed bigger inhibition zone than Gram-negative bacteria (E. coli and Salmonella)

All extracts inhibited Staphylococcus aureus (ATCC 25923), Bacillus (ATCC 25922) and Pseudomonas neruginosa (ATCC 27853) except for A. australis MetOH against $P$. aeruginosa, T. hockingsi MetOH against $E$. coli, and T. hockingsi ethanolic extract against $E$. coli. MIC values of ethanolic extracts were lower than methanolic extracts of pot-pollen

All extracts inhibited Bacillus subtilis (ATCC 11778), Staphylococcus (ATCC 13047), Es Pschulonir (ATCC 25922), E

$\mathrm{IC}_{50}$ : Trigona apicalis $1.05 \pm 0.01 \mathrm{mg} / \mathrm{mL}$, Trigona itama
$3.24 \pm 0.03 \mathrm{mg} / \mathrm{mL}$, Trigona thoracica $0.86 \pm 0.01 \mathrm{mg} / \mathrm{mL}$

DPPH assay: EtOH bee bread was $93.60 \pm 0.0 \%$ inhibition and Hex

ABTS bee bread was $83.81 \pm 0.05 \%$ inhibition.

ABTS assay: EtOH bee bread showed $97.95 \%$ inhibition and Hex bee bread was $71.23 \%$

FRAP assay: T. clavipes recorded the highest with $123.4 \mathrm{mgGAE} / 100 \mathrm{~g}$. Inhibition of $\beta$-carotene: M. q. anthidioides (83.3\%) was the highest followed by $M$. scutellaris $(76.5 \%)$

Fenton-type reaction: $0.91-1.25 \mathrm{mM}$ uric acid equivalents/100 g pot-pollen.
ABTS assays: 193 .

equivalents $/ 100 \mathrm{~g}$ Hydroxyl radical inhibitio bread. Hydroxyl radical inhibition: $54.08 \%$ an ee bread. $97.32 \%$ inhibition $/ 100 \mathrm{~g}$

The highest antioxidant activity was Melipona lateralis kangarumensis for all three tests. 
Table 6. Cont

\begin{tabular}{|c|c|c|c|c|c|}
\hline Stingless Bee Species & Origin & Sample Preparation & Method & Explanation & Reference \\
\hline Tetragonisca angustula & Venezuela & Extraction in $95 \% \mathrm{EtOH}$ & $\begin{array}{l}\text { ABTS, Fenton type reaction, and } \\
\text { hydroxyl radical }\end{array}$ & 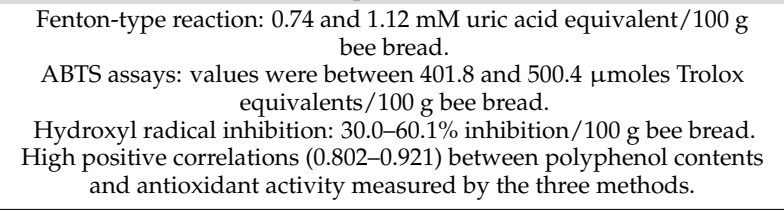 & [84] \\
\hline $\begin{array}{l}\text { Austroplebeia australis, } \\
\text { Tetragonula carbonaria, } \\
\text { Tetragonula hockingsi }\end{array}$ & Australia & $\begin{array}{l}\text { Bee bread was extracted in } \mathrm{MetOH} \\
\text { and EtOH }\end{array}$ & $\begin{array}{l}\text { ABTS, Fenton type reaction, and } \\
\text { hydroxyl radical }\end{array}$ & $\begin{array}{l}\text { The hydroxyl radical inhibition: } 48.6-71.3 \% / 100 \mathrm{~g} \text { bee bread } \\
\text { Fenton-type reaction: } 1.00 \text { and } 1.05 \mathrm{mM} \text { uric acid } / 100 \mathrm{~g} \text { bee bread } \\
\text { ABTS assay: } 229.6 \text { and } 426.4 \mu \mathrm{mol} \text { TEAC } / 100 \mathrm{~g} \text { of bee bread } \\
\text { Overall, EtOH showed higher antioxidant activity than MetOH, but } \\
\text { the results were not statistically different. A positive correlation was } \\
\text { found between the antioxidant activity measured with three methods } \\
\text { and the polyphenol content of bee bread. }\end{array}$ & [100] \\
\hline Melipona fasciculata & Brazil & Extraction in $70 \% \mathrm{EtOH}$ & DPPH, FRAP, and ABTS & $\begin{array}{c}\text { DPPH: IC } \mathrm{I}_{50} 117-597.73 \mu \mathrm{g} / \mathrm{mL} . \\
\text { FRAP: } 0.15-0.99 \mathrm{mmol} \mathrm{Fe} \mathrm{F}^{2+} / \mathrm{g} \\
\text { ABTS: IC } 50.44 .40-235.19 \mu \mathrm{g} / \mathrm{mL}\end{array}$ & [106] \\
\hline Scaptotrigona affinis postica & Brazil & Extraction in $70 \%$ EtOH & DPPH, FRAP, and ABTS & $\begin{array}{c}\text { DPPH: IC } \mathrm{IC}_{50} 273.08 \pm 1.43 \mu \mathrm{g} / \mathrm{mL} \text {. } \\
\text { FRAP: } 0.71 \pm 0.04 \mathrm{Fe}^{2+} / \mathrm{g} \\
\text { ABTS: } \mathrm{IC}_{50} 87.29 \pm 0.06 \mu \mathrm{g} / \mathrm{mL}\end{array}$ & [105] \\
\hline Tetragonula biroi Friese & Thailand & $\begin{array}{l}\text { Extraction in MetOH using two } \\
\text { different methods } \\
\text { (maceration and sonication) }\end{array}$ & DPPH, FRAP, ABTS, LPO & 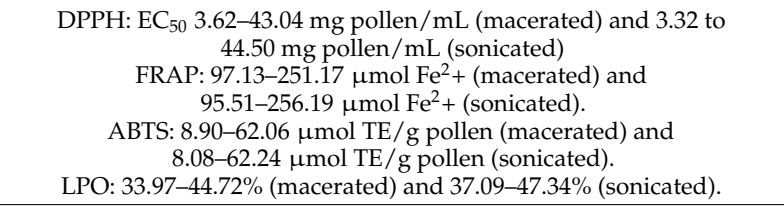 & [107] \\
\hline \multicolumn{6}{|c|}{ Others Therapeutic Properties } \\
\hline Health Benefits & Animal Models & Research Design & Treatment & Effect & \\
\hline Antidiabetic activity & $\begin{array}{l}\text { Thirty-six male Sprague } \\
\text { Dawley rats }\end{array}$ & $\begin{array}{l}\text { Study the antiatherogenic effect of } \\
\text { bee bread in HFD-induced obese rats. } \\
\text { Bee bread of Heterotrigona itama was } \\
\text { administered via oral gavage. }\end{array}$ & $\begin{array}{l}\text { G1: Normal } \\
\text { G2: HFD } \\
\text { G3: HFD + bee bread (high-fat diet } \\
\text { and } 0.5 \mathrm{~g} / \mathrm{kg} / \text { day bee bread) } \\
\text { G4: HFD + orlistat (high-fat diet } \\
\text { and } 10 \mathrm{mg} / \mathrm{kg} / \text { day orlistat) groups }\end{array}$ & 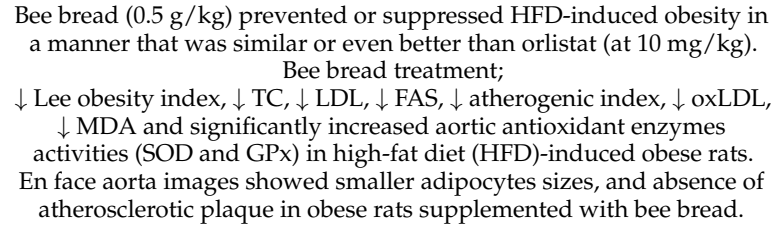 & [104] \\
\hline
\end{tabular}


Table 6. Cont.

Stingless Bee Species

Origin Sample Preparation

Study the bee bread effect on serum renal function parameters, oxidative stress, inflammatory, and Bax in kidneys of HFo obese rats. administered via oral gavage. Thirty-six male Sprague
Dawley rats

\section{Method}

Reference

G1: Control: received rat diet and

water $(1 \mathrm{~mL} / \mathrm{kg})$

group: received HFD and

G3 and G4: bee bread preventive or orlistat preventive

G5 and G6: received HFD and BB

$(0.5 \mathrm{~g} / \mathrm{kg})$ or HFD and orlistat
Bee bread $(0.5 \mathrm{~g} / \mathrm{kg})$ has shown to $\downarrow$ body weight, $\downarrow$ BMI, $\downarrow$ Lee obesity

$$
\begin{aligned}
& \text { index, } \downarrow \text { MDA, } \uparrow \text { TAA, } \uparrow \text { SOD, } \uparrow \text { GPx, } \uparrow \text { GST. } \\
& \downarrow \text { expression of NFkB, TNF-a, IL-1b, and Bax gene. }
\end{aligned}
$$

$(10 \mathrm{mg} / \mathrm{kg})$; BB or orlistat

treatment: received BB $(0.5 \mathrm{~g} / \mathrm{kg})$ or orlistat $(10 \mathrm{mg} / \mathrm{kg})$

G1: saline $(10 \mathrm{~mL} / \mathrm{kg})$

Study the bee bread effect on

duced-oedema paw mice model.

Bee bread EetOH extract of

Anti-inflammatory activity

Adult male Mus musculus mice with dextran-induced Melipona fasciculata was administered paw oedem $5 \mathrm{~h}$ hourly.

G3: bee bread extract $500 \mathrm{mg} / \mathrm{kg}$ G4: cyproheptadine for dextran-induced treatment $(10 \mathrm{mg} / \mathrm{kg})$ and indomethacin for carrageenan-induced $(10 \mathrm{mg} / \mathrm{kg})$ G1: saline $(10 \mathrm{~mL} / \mathrm{kg})$ Study bee bread effect on
Adult male Mus musculus
induced-oedema paw mice mode (1\%

Anti-inflammatory activity Bee bread EtOH extract of Scaptotrigona affinis postica was administered orally and was
monitored for $5 \mathrm{~h}$ with $1 \mathrm{~h}$ interval carrageenan-induced G2: bee bread extract $(250 \mathrm{mg} / \mathrm{kg})$ G3. bee cyproheptadine $\mathrm{mg} / \mathrm{kg}$ cr. cyproheptadine for $(10 \mathrm{mg} / \mathrm{kg})$ and indomethacin for carrageenan-induced $(10 \mathrm{mg} / \mathrm{kg})$

G1: saline $(10 \mathrm{~mL} / \mathrm{kg})$ Adult male Mus musculus mice injected with $0.8 \%$

Bee bread EtOH extract of acetic acid and $2.5 \%$ Melipona fasciculata $\mathrm{w}$ as G2: bee bread extract $(250 \mathrm{mg} / \mathrm{kg})$ 3: bee bread extract $(500 \mathrm{mg} / \mathrm{kg})$ Adult male Mus musculus mice injected with $0.8 \%$ formalin separately

Bee bread EtOH extract of Scaptotrigona affinis postica was administered orally.

G1: saline $(10 \mathrm{~mL} / \mathrm{kg})$ G3: indomethacin $(10 \mathrm{mg} / \mathrm{kg})$

\section{Carrageenan-induced paw oedema test:
G3 significantly $\downarrow$ mice paw oedema by $52 \%$ compared \\ G3 significantly $\downarrow$ mice paw oedema by $52 \%$ compared to control in}

$1 \mathrm{~h}$. After 5 h, G2, G3, and G4 reduced oedema by better $(p<0.001)$

$$
\begin{array}{r}
\text { than G1. } \\
\text { Dextran-induced paw }
\end{array}
$$

G3 significantly $\downarrow$ mice paw oedema by $84 \%$ compared to G4 in $1 \mathrm{~h}$.

After 5 h, G2, G3, and G4 reduced oedema better $(p<0.001)$ than G1.

After $5 \mathrm{~h}, \mathrm{G} 2$, and G3 significantly $\downarrow$ mice paw oedema by similar to G5, but better than G1.

Dextran-induced paw oedema test:

After $5 \mathrm{~h}, \mathrm{G} 2$, and G3 significat $\downarrow$ mice paw oedema by similar to G5 but better than G1.

Acetic acid writhing test:

G3 was more efficient than G4 to reduce abdominal contortions produced, with less than $58 \%$ writhing $(p<0.05)$. Formalin test:

In neurogenic phase, G2 and G3 $\downarrow$ time that the animals passed G4. In inflo $(p>0.05)$ to the mice licking/biting time.

\section{Acetic acid writhing test:}

G2 $\downarrow$ the number of abdominal writhing's by $52 \%$ compared to G $(p<0.05)$, but equal to $\mathrm{G} 3$ Formalin test:

In neurogenic phase, G2 $\downarrow$ time that the animals passed licking/biting the induced paw by $57 \%$, better than G1 and $51 \%$ compared to G3. In than G1 and $96 \%$ compared to G3.

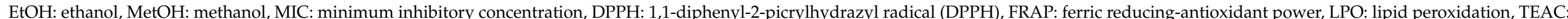

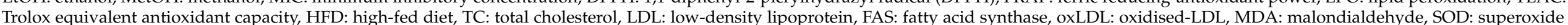

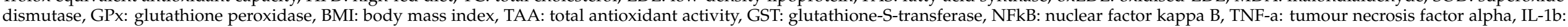
interleukin-1-b, and Bax: B-cell associated protein. 
However, Perez-Perez et al. [100] found similar efficiency between ethanolic and methanolic extract of Austroplebeia australis, Tetragonula carbonaria, and Tetragonula hockingsi bee bread when using ABTS, Fenton type reaction, and hydroxyl radical, respectively. The antioxidant activities also varied according to bee species. Comparison between trigona species showed Trigona thoracica bee bread with the highest DPPH inhibition $\left(\mathrm{IC}_{50} / 0.86 \mathrm{mg} / \mathrm{mL}\right)$ followed by Trigona apicalis $\left(\mathrm{IC}_{50} / 1.05 \mathrm{mg} / \mathrm{mL}\right)$ and Trigona itama $\left(\mathrm{IC}_{50} / 3.24 \mathrm{mg} / \mathrm{mL}\right)[99]$.

Bee bread antioxidant ability corresponds to phenolic compounds $[84,100,107,119]$. Antioxidant activities also depended on the year of pollen collection, botanical origin, and storage time [120].

\subsection{Antidiabetic Properties}

Obesity is a public health concern. According to World Health Organisation [121], in 2016, more than 1.9 billion adults (18 years and above) were overweight with 650 million obese. A wide array of natural products has been assessed for their ability to combat obesity and that includes bee bread.

For example, Heterotrigona itama bee bread reduced Lee obesity index and levels of total cholesterol (TC), low-density lipoprotein (LDL), fatty acid synthase (FAS) activity, atherogenic index, oxidised-LDL (oxLDL), and malondialdehyde (MDA) and significantly increased aortic antioxidant enzymes activities (superoxide dismutase (SOD) and glutathione peroxidase (GPx)) in high-fat diet (HFD)-induced obese rats. En face aorta images showed smaller adipocytes sizes and absence of atherosclerotic plaque in obese rats supplemented with bee bread [104].

In another research, Eleazu et al. [118] studied bee bread effects on obesity-induced renal pathology. The outcomes showed $0.5 \mathrm{~g} / \mathrm{kg} \mathrm{H}$. itama bee bread attenuated renal pathology caused by obesity by diminishing oxidative stress and downregulating the expressions of inflammatory markers and bax-mediated proapoptotic condition in the kidney of HFD obese rats.

\subsection{Anti-Inflammatory Properties}

Some studies also suggest bee bread extract's ability to reduce inflammation. Melipona fasciculata and Scaptotrigona affinis postica ethanolic bee bread extracts were administered in induced-oedema mice model in two separate studies $[105,106]$. The anti-inflammatory responses were time and dose independent. After $5 \mathrm{~h}$, the bee bread treatments were able to reduce the paw volume equivalent to the drug treatment of indomethacin (antiinflammatory) and cyproheptadine (antihistamine). Further analysis identified the possible mechanism of phenolic compounds to inhibit the release of histamine and reduce prostaglandin synthesis [106].

\subsection{Antinociceptive Properties}

Bee bread extract has the ability to block pain detection through its antinociceptive activity. In vivo studies were conducted on pain-induced mice administered with bee bread ethanolic extract of two different species-Melipona fasciculata and Scaptotrigona affinis postica. Upon investigation, Melipona fasciculata bee bread extract (500 mg/kg) reduced the abdominal contort in mice suffering from acetic acid exposure better than indomethacin. Meanwhile, the formalin test showed bee bread extract efficiency similar to those of indomethacin in reducing biting/licking time in mice [106].

In a different study, Lopes et al. [105] investigated the antinociceptive activity using Scaptotrigona affinis postica ethanolic extract at lower dosage $(250 \mathrm{mg} / \mathrm{kg})$. The bee bread treatment showed similar effect to indomethacin in the acetic acid writhing test but significantly better than the drug $(p<0.005)$ in the formalin test. The presence of polyphenols and flavonoids was suggested to be responsible for these activities $[105,106]$. 


\section{Microbiology Properties of Bee Bread}

Bee pollen conversion into bee bread via lactic acid fermentation is linked with microbial action. Bee bread has been assumed to undergo microbial fermentation to increase its nutritional value [37,48]. This theory is termed as "Bee bread maturation" hypothesis [122], a notion that has been proposed since the mid-1990s but recently has been argued [123]. Through these studies, bee bread was found only to be preserved, and there was lack of evidence in nutrient conversion by microbes.

In this section, understanding the bee bread microbial ecology will include data of bee bread from other bee species such as the honeybee and solitary bee due to limited record on stingless bee bee bread microbes. Beneficial bacteria isolated from bee bread, such as $\mathrm{LAB}$, Bifidobacterium, Bacillus, and yeasts from different bee bread species are summarised in Table 7.

Regardless, isolation and identification of microbes from bee bread have been widely reported. Yet, the study on their functional properties towards the bee ecosystem and most importantly, their potential for industrial application is still incomprehensive [37,124]. Some LAB from honeybee bee bread displayed antifungal activity towards foodborne pathogens Aspergillus niger, Zygosaccharomyces rouxii, and Candida sp. [73]. To date, Ngalimat et al. [16] identified Bacillus spp. from Heterotrigona itama bee bread with enzyme and antimicrobial-producing properties. In addition, Mohammad et al. [15] isolated lactic acid bacteria from the same stingless bee species with probiotic potential in vitro. This provides a basis to promote study for the application of beneficial microbes from bee bread in the food industry.

\subsection{Lactic Acid Bacteria}

Lactic acid bacteria (LAB) such as Lactobacillus, Enterococcus, Lactococcus, Leuconostoc, Pediococcus, Streptococcus, Carnobacterium, Aerococcus, Vagococcus, Oenococcus, Tetragenococcus, and Weisella [125] produce lactic acid as a major end product of fermentation. Undeniably, microorganisms such as LAB and yeast are associated with bee bread fermentation process, yet the details of the process are still vague with no conclusive explanation on the exact microorganisms responsible for this process [126]. An attempt to create artificial bee bread using Lactobacillus rhamnosus GG was made [98].

Current literature has conveyed extensive study conferring on microorganisms associated with honeybee bee bread or its ecosystem overall, particularly for Apis mellifera species. Only a few studies have discussed on microorganisms in the stingless bee [37]. The bacterial species found in bee bread across different bee species are diverse. Lactobacillus sp. particularly Lb. kunkeei is commonly found in bee bread [123,127-130]. About $83.9 \%$ of bacteria in bee bread honeybee Apis mellifera belongs to Lactobacillus spp. which is largely composed of Lb. kunkeei [128]. However, Lb. kunkeei was detected in low quantities in fresh bee bread of solitary bee Osmia cornuta and absent in the old bee bread of Osmia coruta and bee bread of H. itama [15,130].

Recently, Mohammad et al. [15] isolated Fructobacillus fructosus from H. itama bee bread. Fructobacillus spp. is a group of fructophilic LAB, which prefer fructose substrate over glucose [131] and can also be found in H. itama honey [132], honeybee Apis mellifera bee pollen, and bee bread $[133,134]$ with the capability to utilise plant lignin in vitro [134].

Culture-independent studies help to provide more useful insight into the bee bread bacterial community, taking into account species which are unculturable under controlled condition. Mattila et al. [126] used 454-pyrosequencing technique to sample the active bacteria in the bee bread of honeybee Apis without cultural bias. Oenococcus and Lactobacillus were the most active microbes in bee bread, comprising $52 \%$ and $60 \%$ of bacteria, respectively, suggesting its important contribution towards bee pollen conversion. 
Table 7. Lactic acid bacteria, nonlactic acid bacteria, and yeasts associated with stingless bee bee bread.

\begin{tabular}{|c|c|c|}
\hline Bacterium & Bee Species & References \\
\hline \multicolumn{3}{|c|}{ Lactic Acid Bacteria (LAB) } \\
\hline Lactobacillus sp. & $\begin{array}{c}\text { Apis mellifera }{ }^{1} \\
\text { Apis sp. }{ }^{1}\end{array}$ & $\begin{array}{c}{[128,129,134]} \\
{[123,126]}\end{array}$ \\
\hline Lactobacillus kunkeei & $\begin{array}{c}\text { Apis mellifera }^{1} \\
\text { Osmia cornuta }^{3} \\
\text { Apis sp. }^{1}\end{array}$ & $\begin{array}{c}{[14,128,135]} \\
{[130]} \\
{[123]}\end{array}$ \\
\hline Lactobacillus mucosae & Apis mellifera ${ }^{1}$ & [128] \\
\hline Lactobacillus musae & Heterotrigona itama $^{2}$ & [15] \\
\hline Lactobacillus crustorum & Heterotrigona itama ${ }^{2}$ & [15] \\
\hline Lactobacillus mindensis & Heterotrigona itama ${ }^{2}$ & {$[15]$} \\
\hline Lactobacillus casei & Apis mellifera $^{1}$ & {$[127]$} \\
\hline Leuconostoc mesenteroides & Heterotrigona itama ${ }^{2}$ & [15] \\
\hline Enterococcus durans & Osmia cornuta $^{3}$ & [130] \\
\hline Enterococcus faecalis & $\begin{array}{c}\text { Osmia cornuta }^{3} \\
\text { Heterotrigona itama }^{2}\end{array}$ & $\begin{array}{l}{[130]} \\
{[15]}\end{array}$ \\
\hline Enterococcus faecium & Osmia cornuta $^{3}$ & [130] \\
\hline Fructobacillus sp. & Apis mellifera $^{1}$ & {$[134]$} \\
\hline Fructobacillus fructosus & Heterotrigona itama $^{2}$ & {$[15]$} \\
\hline Weisella sp & Osmia cornuta $^{3}$ & [130] \\
\hline Weisella confusa & Osmia cornuta ${ }^{3}$ & {$[130]$} \\
\hline Weisella viridescens & Osmia cornuta $^{3}$ & [130] \\
\hline Oenococcus & Apis sp. ${ }^{1}$ & {$[126]$} \\
\hline \multicolumn{3}{|c|}{ Non-LAB } \\
\hline Bifidobacterium sp. & $\begin{array}{c}\text { Apis mellifera }{ }^{1} \\
\text { Apis sp. }{ }^{1}\end{array}$ & $\begin{array}{c}{[14]} \\
{[126]}\end{array}$ \\
\hline Bifidobacterium asteroides & Apis mellifera $^{1}$ & [135] \\
\hline Bacillus sp. & Osmia cornuta $^{3}$ & [130] \\
\hline Bacillus megaterium & Tetragonula biroi Friese ${ }^{2}$ & {$[74]$} \\
\hline Bacillus thuringiensis & Osmia cornuta ${ }^{3}$ & [130] \\
\hline Bacillus licheniformis & $\begin{array}{l}\text { Osmia cornuta }^{3} \\
\text { Apis mellifera }^{1}\end{array}$ & $\begin{array}{l}{[130]} \\
{[136]}\end{array}$ \\
\hline Bacillus pumilus & $\begin{array}{c}\text { Osmia cornuta }^{3} \\
\text { Apis mellifera }^{1} \\
\text { Tetragonula biroi Friese }^{2} \\
\text { Heterotrigona itama }^{2}\end{array}$ & $\begin{array}{c}{[130]} \\
{[136]} \\
{[74]} \\
{[15]}\end{array}$ \\
\hline Bacillus flexus & Tetragonula biroi Friese ${ }^{2}$ & [74] \\
\hline Bacillus coagulans & Tetragonula biroi Friese 2 & {$[74]$} \\
\hline Bacillus subtilis & Osmia cornuta $^{3}$ & [130] \\
\hline & $\begin{array}{c}\text { Tetragonula biroi Friese }{ }^{2} \\
\text { Apis mellifera }{ }^{1}\end{array}$ & $\begin{array}{c}{[74]} \\
{[136]}\end{array}$ \\
\hline Bacillus safensis & Heterotrigona itama $^{2}$ & [15] \\
\hline Bacillus amyloliquefaciens & $\begin{array}{c}\text { Heterotrigona itama }^{2} \\
\text { Tetragonula biroi Friese }\end{array}$ & $\begin{array}{l}{[15]} \\
{[74]}\end{array}$ \\
\hline Bacillus cereus & $\begin{array}{c}\text { Heterotrigona itama }^{2} \\
\text { Tetragonula biroi Friese }\end{array}$ & $\begin{array}{l}{[15]} \\
{[74]}\end{array}$ \\
\hline \multicolumn{3}{|c|}{ Yeast } \\
\hline $\begin{array}{l}\text { Starmerella meliponinorum } \\
\text { Starmerella neotropicalis }\end{array}$ & $\begin{array}{c}\text { Tetragonisca angustula }^{2} \\
\text { Melipona quinquefasciata }\end{array}$ & $\begin{array}{c}{[137,138]} \\
{[139]}\end{array}$ \\
\hline
\end{tabular}

\footnotetext{
${ }^{1}$ Honeybee, ${ }^{2}$ Stingless bee, ${ }^{3}$ Solitary bee.
} 


\subsection{Bacillus}

Lactic acid bacteria have been the integral focus when it comes to bee bread microbial fermentation, but other bacterial species such as Bacillus seem to hold its importance in the bee bread metabolic conversion. Although Gilliam [136] found Bacillus in honeybee bee bread, the lactic acid production is less efficient than lactic acid bacteria fermentation. The functional role of Bacillus in bee bread was not defined until now. One of the early assumptions of Bacillus role in bee bread production was to produce enzymes for bee pollen conversion [140]. Few Bacillus spp. such as B. subtilis [141], B. megaterium [142], and $B$. licheniformis [143] have exhibited fermentation ability either using glucose, fructose, or sucrose as substrate. These species have been isolated in bee bread of stingless bee Melipona fasciata [140], H. itama [15,16], Tetragonula biroi Friese [74], honeybee Apis mellifera [136], and solitary bee Osmia cornuta [130]. However, Bacillus fermentation using bee pollen or bee bread is not yet reported.

\subsection{Yeast}

Fermentation is commonly linked with yeast. Yeasts association with fermentation of bee bread has been proposed by researchers. An early study by Gilliam [144] discovered the least yeast count in Apis mellifera bee bread as opposed to bee pollen and flower pollen. Several studies had also attempted to describe the yeast communities not only in bee bread but also in bee colonies. In Brazil, yeasts such as Starmerella and Candida spp. are the most frequently found in the body, pollen, honey, and propolis of stingless bee species of Tetragonisca angustula, Melipona quadrifasciata, and Frieseomelitta varia [137]. Starmerella spp. also has been highly associated with other stingless bee species. Teixeira et al. [137] found Tetragonisca angustula's pollen to harbour Starmerella meliponinorum. Meanwhile, Daniel et al. [139] have characterised 25 yeast species with Starmerella neotropicalis as the most abundant in Melipona quinquefasciata bee bread and bee pollen.

\subsection{Association of Bee Gut Microbiota and Bee Bread Microbiota}

Natural fermentation of bee bread is somehow related to bee gut microbiota [13]. Understanding the bee gut microbiome and the microbial fermenter involved in pollen fermentation could provide valuable information for biotechnological applications [64]. Contribution of bee gut towards bee bread fermentation was first suggested when 6 Lactobacillus and 3 Bifidobacterium strains were isolated from A. mellifera bee bread [129], which are similar to the bacteria isolated from its gut [145].The early assumption was made by theorising bee gut transmission to bee bread through regurgitated honey during bee pollen agglutination process.

The scale of contribution of bee gut towards bee bread microbial inoculation has been studied by Mattila et al. [126]. It was found that only $10 \%$ of the bacterial species were commonly shared between bee gut and bee bread. The low impact of bee gut microbiota in contributing a substantial amount of microbes in bee bread fermentation was also supported by Anderson et al. [146] and Corby-Harris et al. [147]. The dominant bacteria in bee bread and honeybee Apis mellifera bee gut were also found in fresh flower and nectar, suggesting common horizontal transmission [146]. Nevertheless, it can be concluded that bee gut and also the hive environment contribute towards the bacteria residency in bee bread.

Understanding bee gut microbiome could get complicated because of diverse bacterial communities [145]. By far, the gut microbiota of honeybee Apis spp. is widely discussed $[148,149]$ while only a few researchers have attempted to characterise the stingless bee gut microbiota. For instance, the culture-dependent analysis performed on stingless bee Meliponini beecheii (Central America), M. bocandei (Africa), and Trigona sp. (Borneo and Thailand) revealed their honey stomach harbours Lactobacillus and Bifidobacterium species [150].

The gut microbiome not only varies between species but also between colonies. For example, Leonhardt and Kaltenpoth [151] focused on LAB-bee associated with Australian 
stingless bee species (Austroplebeia australis, Tetragonula carbonaria, and Tetragonula hockingsi). Interestingly, the microbiome of these stingless bee is different intercolonies but almost similar to the microbiome of honeybee Apis mellifera [150]. Comparison between three different eusocial bees (honeybee, bumblebee, and stingless bee) found Gilliamella, Bifidobacterium, Lactobacillus Firm-4 and Lactobacillus Firm-5 comprising the core of the gut's microbiome, with Meliponini as the most diverse one [152].

Bee gut microbiota is maternally inherited [66], acquired through bee faeces or oral trophallaxis [153] and environmental sources such as hive and flower [66]. Functional studies of A. mellifera gut microbiota through metagenomic analysis showed a possible link of these microbes to bee protection against pathogens and nutrition acquisition by degrading the pollen wall [12]. Zheng et al. [154] found enrichment of galacturonic acid, a pectin constituent in the honeybee ileum, which suggests pectin degradation. However, no in vitro and in vivo studies have yet to identify the bee gut species responsible for this fermentation process.

Understanding the functional role of bee gut, especially in bee bread fermentation, could be useful. According to Anderson et al. [116], fermentation helps to preserve bee bread environment rather than provide nutrient enrichment. Vásquez et al. [150] demonstrated the ability of LAB strains found in bee bread and honeybee Apis mellifera to protect bee bread against bee pathogen M. plutonius in vivo and in vitro. However, these studies were heavily based upon honeybee Apis sp. More studies should be conducted on stingless bee, whether it will have similar outcomes or not.

\section{Conclusions}

This review paper has summarised the physicochemical properties and health benefits of stingless bee bee bread and has discussed the microbial ecology of bee bread in general in relation to the bee gut. Bee bread is one of the overlooked stingless bee products, highly competing with Apis bee pollen in the current market and research focus. The food industry has seen tremendous changes in food trends from processed food to natural products with scientifically proven health benefits. The collective pieces of evidence in recent years have shown the potential of the stingless bee bee bread to be developed as a food ingredient, feed, or a supplement. It is rich in micronutrients, minerals, and phenolic compounds. However, research on their therapeutic values is still scarce. There are wide research opportunities to delve in on the bioactive compounds and their biological properties in vitro and in vivo. More research should be conducted so that an international standard for bee bread of stingless bee could be developed. More research on stingless bee bee bread can add to its commercial value and push to develop the meliponiculture industry. Bee bread has emerged as a reservoir to isolate beneficial microbes that contribute to bee bread preservation and can also provide newfound application in the industries.

Author Contributions: Conceptualisation, N.Z.; writing-original draft preparation, S.M.M.; writing —review and editing, S.M.M., N.Z., N.-K.M.A.-R.; visualisation, S.M.M.; supervision, N.Z.; funding acquisition, N.Z. All authors have read and agreed to the published version of the manuscript.

Funding: This research was funded by the Universiti Putra Malaysia under the Putra Grant Scheme: GP/2017/9568900.

Conflicts of Interest: The authors declare no conflict of interest.

\section{References}

1. Heard, T. The Australian Native Bee Book: Keeping Stingless Bee Hives for Pets, Pollination and Delectable Sugarbag Honey; Sugarbag Bees: Queensland, Australia, 2016.

2. Michener, C.D. The Bees of the World; JHU Press: Baltimore, MD, USA, 2000; Volume 85.

3. Mizrahi, A.; Lensky, Y. Bee Products: Properties, Applications, and Apitherapy; Springer Science \& Business Media: Berlin/Heidelberg, Germany, 2013.

4. Kieliszek, M.; Piwowarek, K.; Kot, A.M.; Błażejak, S.; Chlebowska-Śmigiel, A.; Wolska, I. Pollen and bee bread as new healthoriented products: A review. Trends Food Sci. Technol. 2018, 71, 170-180. [CrossRef] 
5. Vit, P.; Pedro, S.R.M.; Roubik, D.W. Pot-Pollen in Stingless Bee Melittology; Springer International Publishing: Cham, Switzerland, 2018.

6. Thakur, M.; Nanda, V. Composition and functionality of bee pollen: A review. Trends Food Sci. Technol. 2020, 98, 82-106. [CrossRef]

7. Mărgăoan, R.; Strant, M.; Varadi, A.; Topal, E.; Yücel, B.; Cornea-Cipcigan, M.; Campos, M.G.; Vodnar, D.C. Bee Collected Pollen and Bee Bread: Bioactive Constituents and Health Benefits. Antioxidants 2019, 8, 568. [CrossRef] [PubMed]

8. Feas, X.; Vazquez-Tato, M.P.; Estevinho, L.; Seijas, J.A.; Iglesias, A. Organic bee pollen: Botanical origin, nutritional value, bioactive compounds, antioxidant activity and microbiological quality. Molecules 2012, 17, 8359-8377. [CrossRef] [PubMed]

9. Vit, P.; Albore, G.R.D.; Barth, O.M.; Peña-Vera, M.; Pérez-Pérez, E. Characterization of pot-pollen from Southern Venezuela. In Pot-Pollen in Stingless Bee Melittology; Vit, P., Pedro, S.R.M., Roubik, D.W., Eds.; Springer International Publishing: Cham, Switzerland, 2018; pp. 361-375.

10. Denisow, B.; Denisow-Pietrzyk, M. Biological and therapeutic properties of bee pollen: A review. J. Sci. Food Agric. 2016, 96, 4303-4309. [CrossRef] [PubMed]

11. Khalifa, S.A.M.; Elashal, M.; Kieliszek, M.; Ghazala, N.E.; Farag, M.A.; Saeed, A.; Sabir, J.S.M.; Battino, M.; Xiao, J.; Zou, X.; et al. Recent insights into chemical and pharmacological studies of bee bread. Trends Food Sci. Technol. 2020, 97, 300-316. [CrossRef]

12. Engel, P.; Martinson, V.G.; Moran, N.A. Functional diversity within the simple gut microbiota of the honey bee. Proc. Natl. Acad. Sci. USA 2012, 109, 11002-11007. [CrossRef]

13. Ramos, O.Y.; Basualdo, M.; Libonatti, C.; Vega, M.F. Current status and application of lactic acid bacteria in animal production systems with a focus on bacteria from honey bee colonies. J. Appl. Microbiol. 2020, 128, 1248-1260. [CrossRef]

14. Vásquez, A.; Olofsson, T.C. The lactic acid bacteria involved in the production of bee pollen and bee bread. J. Apic. Res. 2009, 48, 189-195. [CrossRef]

15. Mohammad, S.M.; Mahmud-Ab-Rashid, N.K.; Zawawi, N. Probiotic properties of bacteria isolated from bee bread of stingless bee Heterotrigona itama. J. Apic. Res. 2020, 0, 1-16. [CrossRef]

16. Ngalimat, M.S.; Rahman, R.N.Z.R.A.; Yusof, M.T.; Syahir, A.; Sabri, S. Characterisation of bacteria isolated from the stingless bee, Heterotrigona itama, honey, bee bread and propolis. PeerJ 2019, 7, e7478. [CrossRef]

17. Smith, J.P.; Heard, T.A.; Beekman, M.; Gloag, R. Flight range of the Australian stingless bee Tetragonula carbonaria (Hymenoptera: Apidae). Austral Entomol. 2016, 56, 50-53. [CrossRef]

18. Araujo, E.D.; Costa, M.; Chaud-Netto, J.; Fowler, H.G. Body size and flight distance in stingless bees (Hymenoptera: Meliponini): Inference of flight range and possible ecological implications. Braz. J. Biol. 2004, 64, 563-568. [CrossRef] [PubMed]

19. Basari, N.; Ramli, S.N.; Khairi, N.S.M. Food reward and distance influence the foraging pattern of stingless bee, Heterotrigona itama. Insects 2018, 9, 138. [CrossRef] [PubMed]

20. Kiew, R.; Muid, M. Beekeeping in Malaysia: Pollen Atlas; Malaysian Beekeeping Research and Development Team: Serdang, Malaysia, 1991.

21. Ghazi, R.; Zulqurnain, N.S.; Azmi, W.A. Melittopalynological Studies of Stingless Bees from the East Coast of Peninsular Malaysia. In Pot-Pollen in Stingless Bee Melittology; Vit, P., Pedro, S.R.M., Roubik, D.W., Eds.; Springer International Publishing: Cham, Switzerland, 2018; pp. 77-88.

22. Mohammad, S.M.; Mahmud-Ab-Rashid, N.K.; Zawawi, N. Botanical Origin and Nutritional Values of Bee Bread of Stingless Bee (Heterotrigona itama) from Malaysia. J. Food Qual. 2020, 2020, 15-17. [CrossRef]

23. Lob, S.; Afiffi, N.; Razak, S.B.A.; Ibrahim, N.F.; Nawi, I.H.M. Composition and identification of pollen collected by stingless bee (Heterotrigona itama) in forested and coastal area of Terengganu, Malaysia. Malays. Appl. Biol. 2017, 46, 227-232.

24. Thakodee, T.; Deowanish, S.; Duangmal, K. Melissopalynological analysis of stingless bee (Tetragonula pagdeni) honey in Eastern Thailand. J. Asia. Pac. Entomol. 2018, 21, 620-630. [CrossRef]

25. Zubaidah, A.H.; Bahri, A.R.S.; Sanusi, J.; Adam, N.A.; Azura, A.; Hamzah, A.H. Application of scanning electron microscope in palynology study of floral resources by indo-malayan stingless bees genus tetragonula. Malays. J. Microsc. 2018, 14, 95-102.

26. Zaki, N.N.M.; Razak, S.B.A. Pollen profile by stingless bee (Heterotrigona itama) reared in rubber smallholding environment at Tepoh, Terengganu. Malays. J. Microsc. 2018, 14, 38-54.

27. Selvaraju, K.; Vikram, P.; Soon, J.M.; Krishnan, K.T.; Mohammed, A. Melissopalynological, physicochemical and antioxidant properties of honey from West Coast of Malaysia. J. Food Sci. Technol. 2019, 56, 2508-2521. [CrossRef]

28. Majid, M.; Ellulu, M.S.; Bakar, M.F.A. Melissopalynological Study, Phenolic Compounds, and Antioxidant Properties of Heterotrigona itama Honey from Johor, Malaysia. Scientifica 2020, 2020, 1-9. [CrossRef] [PubMed]

29. Silva, T.M.S.; Camara, C.A.; Lins, A.C.S.; de Fátima Agra, M.; Silva, E.M.S.; Reis, I.T.; Freitas, B.M. Chemical composition, botanical evaluation and screening of radical scavenging activity of collected pollen by the stingless bees Melipona rufiventris (Uruçu-amarela). An. Acad. Bras. Cienc. 2009, 81, 173-178. [CrossRef] [PubMed]

30. Absy, M.L.; Rech, A.R.; Ferreira, M.G. Pollen Collected by Stingless Bees: A Contribution to Understanding Amazonian Biodiversity. In Pot-Pollen in Stingless Bee Melittology; Vit, P., Pedro, S.R.M., Roubik, D.W., Eds.; Springer International Publishing: Cham, Switzerland, 2018; pp. 29-46.

31. Roubik, D.W.; Patiño, J.E.M. The Stingless Honey Bees (Apidae, Apinae: Meliponini) in Panama and Pollination Ecology from Pollen Analysis. In Pot-Pollen in Stingless Bee Melittology; Vit, P., Pedro, S.R.M., Roubik, D.W., Eds.; Springer International Publishing: Cham, Switzerland, 2018; pp. 47-66. 
32. Barth, O.M.; da Silva de Freitas, A.; Vanderborgth, B. Pollen Storage by Melipona quadrifasciata anthidioides in a Protected Urban Atlantic Forest Area of Rio de Janeiro, Brazil. In Pot-Pollen in Stingless Bee Melittology; Vit, P., Pedro, S.R.M., Roubik, D.W., Eds.; Springer International Publishing: Cham, Switzerland, 2018; pp. 103-109.

33. De Jesus Oliveira, D.; dos Santos, D.R.; Andrade, B.R.; do Nascimento, A.S.; da Silva, M.O.; da Cruz Mercês, C.; Lucas, C.I.S.; da Silva, S.M.P.C.; de Carvalho, P.D.; de Lima Silva, F.; et al. Botanical origin, microbiological quality and physicochemical composition of the Melipona scutellaris pot-pollen ('samburá') from Bahia (Brazil) Region. J. Apic. Res. 2020, 1-13. [CrossRef]

34. Vit, P.; Pulcini, P. Diastase and invertase activities in Meliponini and Trigonini honeys from Venezuela. J. Apic. Res. 1996, 35, 57-62. [CrossRef]

35. Leonhardt, S.D.; Dworschak, K.; Eltz, T.; Blüthgen, N. Foraging loads of stingless bees and utilisation of stored nectar for pollen harvesting. Apidologie 2007, 38, 125-135. [CrossRef]

36. Campos, M.G.R.; Bogdanov, S.; De Almeida-Muradian, L.B.; Szczesna, T.; Mancebo, Y.; Frigerio, C.; Ferreira, F. Pollen composition and standardisation of analytical methods. J. Apic. Res. 2008, 47, 154-161. [CrossRef]

37. Menezes, C.; Vollet-Neto, A.; Andrés, F.; León, F.; Venturieri, G.C.; Imperatriz-Fonseca, V.L. The Role of Useful Microorganisms to Stingless Bees and Stingless Beekeeping. In Pot-Honey: A Legacy of Stingless Bees; Springer: New York, NY, USA, $2013 ;$ pp. 153-171.

38. Ivanišová, E.; Kačániová, M.; Frančáková, H.; Petrová, J.; Hutková, J.; Brovarskyi, V.; Velychko, S.; Adamchuk, L.; Schubertová, Z.; Musilová, J. Bee bread-Perspective source of bioactive compounds for future. Potravinarstvo 2015, 9, 592-598. [CrossRef]

39. De Oliveira Alves, R.M.; Carvalho, C.A.L. Pot-Pollen 'Samburá' Marketing in Brazil and Suggested Legislation. In Pot-Pollen in Stingless Bee Melittology; Vit, P., Pedro, S.R.M., Roubik, D.W., Eds.; Springer International Publishing: Cham, Switzerland, 2018; pp. $435-443$.

40. Akhmetova, R.; Sibgatullin, J.; Garmonov, S.; Akhmetova, L. Technology for extraction of bee-bread from the honeycomb. Procedia Eng. 2012, 42, 1822-1825. [CrossRef]

41. Wilara. Pollen and Bee Bread Harvesting. Available online: https://wilara.lt/en/bitininkyste/bee-bread-pollen-and-propolisharvesting/pollen-and-bee-bread-harvesting/ (accessed on 6 October 2020).

42. Anđelković, B.; Jevtić, G.; Mladenović, M.; Marković, J.; Petrović, M.; Nedić, N. Quality of pollen and honey bee bread collected in spring. J. Hyg. Eng. Des. 2012, 1, 275-277.

43. Herbert, E.W.; Bee, B.; Shimanuki, H. Chemical composition and nutritive value of bee-collected and bee-stored pollen. Apidologie 1978, 9, 33-40. [CrossRef]

44. Nicolson, S.W.; Human, H. Chemical composition of the 'low quality' pollen of sunflower (Helianthus annuus, Asteraceae). Apidologie 2012, 44, 144-152. [CrossRef]

45. Human, H.; Nicolson, S.W. Nutritional content of fresh, bee-collected and stored pollen of Aloe greatheadii var. davyana (Asphodelaceae). Phytochemistry 2006, 67, 1486-1492. [CrossRef] [PubMed]

46. Degrandi-Hoffman, G.; Eckholm, B.J.; Huang, M.H. A comparison of bee bread made by Africanized and European honey bees (Apis mellifera) and its effects on hemolymph protein titers. Apidologie 2013, 44, 52-63. [CrossRef]

47. Duarte, A.W.F.; Vasconcelos, M.R.D.S.; Oda-Souza, M.; de Oliveira, F.F.; López, A.M.Q. Honey and bee pollen produced by meliponini (Apidae) in alagoas, brazil: Multivariate analysis of physicochemical and antioxidant profiles. Food Sci. Technol. 2018, 38, 493-503. [CrossRef]

48. Gilliam, M. Identifiation and roles of non-pathogenic microflora associated with honey bees. FEMS Microbiol. Lett. 2000, 155, 1-10. [CrossRef]

49. Habryka, C.; Kruczek, M.; Drygas, B. Bee products used in apitherapy. World Sci. News 2016, 48, $254-258$.

50. Urcan, A.C.; Al Marghitas, L.; Dezmirean, D.S.; Bobis, O.; Bonta, V.; Muresan, C.I.; Margaoan, R. Chemical Composition and Biological Activities of Beebread-Review. Bull. Univ. Agric. Sci. Vet. Med. Cluj-Napoca. Anim. Sci. Biotechnol. 2017, 74, 6-14. [CrossRef]

51. Fernandes-da Silva, P.G.; Serrão, J.E. Nutritive value and apparent digestibility of bee-collected and bee-stored pollen in the stingless bee, Scaptotrigona postica Latr. (hymenoptera, apidae, meliponini). Apidologie 2000, 31, 39-45. [CrossRef]

52. Nicolson, S.W.; Da Silva Das Neves, S.; Human, H.; Pirk, C.W.W. Digestibility and nutritional value of fresh and stored pollen for honey bees (Apis mellifera scutellata). J. Insect Physiol. 2018, 107, 302-308. [CrossRef]

53. Ramalho, M.; Imperatriz-Fonseca, V.L.; Giannini, T.C. Within-colony size variation of foragers and pollen load capacity in the stingless bee Melipona quadrifasciata anthidioides Lepeletier (Apidae, Hymenoptera). Apidologie 1998, 29, 221-228. [CrossRef]

54. Ramalho, M.; Giannini, T.C.; Malagodi-braga, K.S.; Vera, L.; Imperatriz-fonseca, V.L.; Pollen, V.L. Pollen Harvest by Stingless Bee Foragers Pollen harvest by stingless bee foragers (Hymenoptera, Apidae, Meliponinae). Grana 2009, 33, 239-244. [CrossRef]

55. García-García, M.C.; Ortiz, P.L.; Dapena, M.J.D. Variations in the weights of pollen loads collected by Apis mellifera L. Grana 2004, 43, 183-192. [CrossRef]

56. Modro, A.F.H.; Silva, I.C.; Luz, C.F.P.; Message, D. Analysis of pollen load based on color, physicochemical composition and botanical source. An. Acad. Bras. Cienc. 2009, 81, 281-285. [CrossRef] [PubMed]

57. Bogdanov, S. Pollen: Production, Nutrition and Health: A Review. Bee Product Science. 2017, pp. 1-36. Available online: https:/ / www.bee-hexagon.net/ (accessed on 13 February 2019).

58. Halbritter, H.; Ulrich, S.; Grimsson, F.; Weber, M.; Zetter, R.; Hesse, M.; Buchner, R.; Svojtka, M.; Frosch-Radivo, A. Pollen Terminology: An Illustrated Handbook; Springer Science \& Business Media: Berlin/Heidelberg, Germany, 2009. 
59. TRoulston, H.I.; Cane, J.H. Plant Systematics Pollen nutritional content and digestibility for animals. Plant Syst. Evol. 2000, 222, 187-188. [CrossRef]

60. Almeida-Muradian, L.B.; Pamplona, L.C.; Coimbra, S.; Barth, O.M. Chemical composition and botanical evaluation of dried bee pollen pellets. J. Food Compos. Anal. 2005, 18, 105-111. [CrossRef]

61. De Souza, R.R.; de Abreu, V.H.R.; de Novais, J.S. Melissopalynology in Brazil: A map of pollen types and published productions between 2005 and 2017. Palynology 2018, 43, 690-700. [CrossRef]

62. Louveaux, J.; Maurizio, A.; Vorwohl, G. Methods of Melissopalynology. Bee World 1978, 59, 139-157. [CrossRef]

63. Ibrahim, I.F.; Balasundram, S.K.; Abdullah, N.A.P.; Alias, M.S.; Mardan, M. Morphological Characterization of Pollen Collected by Apis Dorsata from Tropical Rainforest. Int. J. Bot. 2012, 8, 96-106. [CrossRef]

64. Villegas-Plazas, M.; Figueroa-Ramírez, J.; Portillo, C.; Monserrate, P.; Tibatá, V.; Sánchez, O.A.; Junca, H. Yeast and Bacterial Composition in Pot-Pollen Recovered from Meliponini in Colombia: Prospects for a Promising Biological Resource. In Pot-Pollen in Stingless Bee Melittology; Vit, P., Pedro, S.R.M., Roubik, D.W., Eds.; Springer International Publishing: Cham, Switzerland, 2018; pp. 263-279.

65. Komosinska-Vassev, K.; Olczyk, P.; Kaźmierczak, J.; Mencner, L.; Olczyk, K. Bee pollen: Chemical composition and therapeutic application. Evid.-Based Complement. Altern. Med. 2015, 2015, 297425. [CrossRef]

66. McFrederick, Q.S.; Wcislo, W.T.; Taylor, D.R.; Ishak, H.D.; Dowd, S.E.; Mueller, U.G. Environment or kin: Whence do bees obtain acidophilic bacteria? Mol. Ecol. 2012, 21, 1754-1768. [CrossRef]

67. Kostić, A.Ž.; Barać, M.B.; Stanojević, S.P.; Milojković-Opsenica, D.; Tešić, Ž.L.; Šikoparija, B.; Radišić, P.; Prentović, M.; Pešić, M.B. Physicochemical composition and techno-functional properties of bee pollen collected in Serbia. LWT Food Sci. Technol. 2015, 62, 301-309. [CrossRef]

68. Szczęsna, T. Protein content and amino acid composition of bee-collected pollen from selected botanical origins. J. Apic. Sci. 2006, 50, 81-90. [CrossRef]

69. Ares, A.M.; Valverde, S.; Bernal, J.L.; Nozal, M.J.; Bernal, J. Extraction and determination of bioactive compounds from bee pollen. J. Pharm. Biomed. Anal. 2018, 147, 110-124. [CrossRef] [PubMed]

70. Pascoal, A.; Rodrigues, S.; Teixeira, A.; Feás, X.; Leticia, M. Biological activities of commercial bee pollens: Antimicrobial, antimutagenic, antioxidant and anti-inflammatory. Food Chem. Toxicol. 2014, 63, 233-269. [CrossRef] [PubMed]

71. De Oliveira Alves, R.M.; da Silva Sodré, G.; Carvalho, C.A.L. Chemical, microbiological and palynological composition of the 'Sambura' Melipona scutellaris pot pollen. In Pot-Pollen in Stingless Bee Melittology; Vit, P., Pedro, S.R.M., Roubik, D.W., Eds.; Springer International Publishing: Cham, Switzerland, 2018; pp. 349-360.

72. Combey, R. Microbial and Qualitative Analyses of Stingless Bee Bread using Dry Preservation Methods. Eur. J. Zool. Res. 2017, $5,45-50$.

73. Janashia, I.; Choiset, Y.; Jozefiak, D.; Déniel, F.; Coton, E.; Moosavi-Movahedi, A.A.; Chanishvili, N.; Haertlé, T. Beneficial Protective Role of Endogenous Lactic Acid Bacteria Against Mycotic Contamination of Honeybee Beebread. Probiotics Antimicrob. Proteins 2018, 10, 638-646. [CrossRef]

74. Belina-Aldemita, M.D.; Fraberger, V.; Schreiner, M.; Domig, K.J.; D'Amico, S. Safety aspects of stingless bee pot-pollen from the Philippines. Die Bodenkultur J. Land Manag. Food Environ. 2020, 71, 87-100. [CrossRef]

75. Kostić, A.Ž.; Milinčić, D.D.; Petrović, T.; Krnjaja, V.; Stanojevic, S.P.; Barać, M.B.; Tešić, Ž.L.; Pešić, M.B. Mycotoxins and Mycotoxin Producing Fungi in Pollen: Review. Toxins 2019, 11, 64. [CrossRef]

76. Barene, I.; Daberte, I.; Siksna, S. Investigation of Bee Bread and Development of Its Dosage Forms. Med. Teor. Pract. 2015, 21, 16-22. [CrossRef]

77. Ismail, W.I.W.; Hussin, N.N.; Mazlan, S.N.F.; Hussin, N.H.; Radzi, M.N.F.M. Physicochemical Analysis, Antioxidant and Anti Proliferation Activities of Honey, Propolis and Beebread Harvested from Stingless Bee. IOP Conf. Ser. Mater. Sci. Eng. 2018, 440, 1-7. [CrossRef]

78. Othman, Z.; Ghazali, W.S.W.; Nordin, L.; Omar, N.; Mohamed, M. Nutritional, Phytochemical and Antioxidant Analysis of Bee Bread from Different Regions of Malaysia. Indian J. Pharm. Sci. 2019, 81, 955-960. [CrossRef]

79. Mohd, K.S.; Zin, N.B. Chemical and Biological Investigation of Apiculture Products from Stingless Bees Heterotrigona itama. J. Agrobiotechnol. 2020, 11, 7-19. [CrossRef]

80. Chuttong, B.; Phongphisutthinant, R.; Sringarm, K.; Burgett, M.; Barth, O.M. Nutritional Composition of Pot-Pollen from Four Species of Stingless Bees (Meliponini) in Southeast Asia. In Pot-Honey: A Legacy of Stingless Bees; Springer: Cham, Switzerland, 2018; pp. 313-324.

81. Vit, P.; Santiago, B.; Pedro, S.R.; Perez-Perez, E.; Pena-Vera, M. Chemical and bioactive characterization of pot-pollen produced by Melipona and Scaptotrigona stingless bees from Paria Grande, Amazonas State, Venezuela. Emir. J. Food Agric. 2016, 28 , 78-84. [CrossRef]

82. Rebelo, K.S.; Ferreira, A.G.; Carvalho-Zilse, G.A. Physicochemical characteristics of pollen collected by Amazonian stingless bees. Ciência Rural 2016, 46, 927-932. [CrossRef]

83. Belina-aldemita, M.D.; Opper, C.; Schreiner, M.; D'Amico, S. Nutritional composition of pot-pollen produced by stingless bees (Tetragonula biroi Friese) from the Philippines. J. Food Compos. Anal. 2019, 82, 103215. [CrossRef] 
84. Vit, P.; Santiago, B.; Peña-Vera, M.; Pérez-Pérez, E. Chemical Characterization and Bioactivity of Tetragonisca angustula Pot-Pollen from Mérida, Venezuela. In Pot-Pollen in Stingless Bee Melittology; Vit, P., Pedro, S.R.M., Roubik, D.W., Eds.; Springer International Publishing: Cham, Switzerland, 2018; pp. 339-347.

85. Bárbara, M.S.; Machado, C.S.; Sodré, G.D.S.; Dias, L.G.; Estevinho, L.M.; de Carvalho, C.A.L. Microbiological assessment, nutritional characterization and phenolic compounds of bee pollen from Mellipona mandacaia Smith, 1983. Molecules 2015, 20, 12525-12544. [CrossRef]

86. Contreras-Oliva, A.; Perez-Sato, J.A.; Gómez-Merino, F.C.; López-Garay, L.A.; Villanueva-Gutiérrez, R.; Crosby-Galván, M.M.; Trejo-Téllez, L.I. Characterization of Scaptotrigona mexicana pot-pollen from Veracruz, Mexico. In Pot-Pollen in Stingless Bee Melittology; Vit, P., Pedro, S.R.M., Roubik, D.W., Eds.; Springer International Publishing: Cham, Switzerland, 2018 ; pp. $325-337$.

87. da Silva, G.R.; da Natividade, T.B.; Camara, C.A.; da Silva, E.M.S.; dos Santos, F.D.A.R.; Silva, T.M.S. Identification of Sugar, Amino Acids and Minerals from the Pollen of Jandaíra Stingless Bees (Melipona subnitida). Food Nutr. Sci. 2014, 5, $1015-1021$. [CrossRef]

88. Omar, W.A.W.; Yahaya, N.; Ghaffar, Z.A.; Fadzilah, N.H. GC-MS Analysis of Chemical Constituents in Ethanolic Bee Pollen Extracts from Three Species of Malaysian Stingless Bee. J. Apic. Sci. 2019, 62, 275-284. [CrossRef]

89. Al-Sherif, A.A.; Mazeed, A.M.; Ewis, M.A.; Nafea, E.A.; Hagag, E.S.E.; Kamel, A.A. Activity of salivary glands in secreting honey-elaborating enzymes in two subspecies of honeybee (Apis mellifera L). Physiol. Entomol. 2017, 42, 397-403. [CrossRef]

90. Vossler, F.G. Broad Protein Spectrum in Stored Pollen of Three Stingless Bees from the Chaco Dry Forest in South America (Hymenoptera, Apidae, Meliponini) and Its Ecological Implications. Psyche 2015, 2015, 13-15. [CrossRef]

91. Manning, R. Fatty acids in pollen: A review of their importance for honey bees. Bee World 2001, 82, 37-41. [CrossRef]

92. Mărgăoan, R.; Mărghitaş, L.A.; Dezmirean, D.S.; Dulf, F.V.; Bunea, A.; Socaci, S.A.; Bobiş, O. Predominant and Secondary Pollen Botanical Origins Influence the Carotenoid and Fatty Acid Profile in Fresh Honeybee-Collected Pollen. J. Agric. Food Chem. 2014, 62, 6306-6316. [CrossRef] [PubMed]

93. Szczessna, T. Long-chain fatty acids composition of honeybee-collected pollen. J. Apic. Sci. 2006, 50, 65-79.

94. Kaplan, M.; Karaoglu, Ö.; Eroglu, N.; Silici, S. Fatty acid and proximate composition of bee bread. Food Technol. Biotechnol. 2016, 54, 497-504. [CrossRef] [PubMed]

95. Massaro, C.F.; Villa, T.F.; Hauxwell, C. Metabolomics Analysis of Pot-Pollen from Three Species of Australian Stingless Bees (Meliponini). In Pot-Pollen in Stingless Bee Melittology; Vit, P., Pedro, S.R.M., Roubik, D.W., Eds.; Springer International Publishing: Cham, Switzerland, 2018; pp. 401-417.

96. Zhang, H.; Tsao, R. Dietary polyphenols, oxidative stress and antioxidant and anti-inflammatory effects. Curr. Opin. Food Sci. 2016, 8, 33-42. [CrossRef]

97. Urcan, A.C.; Criste, A.D.; Dezmirean, D.S.; Mărgăoan, R.; Caeiro, A.; Campos, M.G. Similarity of data from bee bread with the same taxa collected in India and Romania. Molecules 2018, 23, 2491. [CrossRef]

98. Kaškonienè, V.; Katilevičiūtè, A.; Kaškonas, P.; Maruška, A. The impact of solid-state fermentation on bee pollen phenolic compounds and radical scavenging capacity. Chem. Pap. 2018, 72, 2115-2120. [CrossRef]

99. Fadzilah, N.H.; Jaapar, M.F.; Jajuli, R.; Adnan, W.; Omar, W. Total phenolic content, total flavonoid and antioxidant activity of ethanolic bee pollen extracts from three species of Malaysian stingless bee. J. Apic. Res. 2017, 8839, 1-6. [CrossRef]

100. Pérez-Pérez, E.; Sulbarán-Mora, M.; Barth, O.M.; Massaro, C.F.; Vit, P. Bioactivity and Botanical Origin of Austroplebeia and Tetragonula Australian Pot-Pollen. In Pot-Pollen in Stingless Bee Melittology; Vit, P., Pedro, S.R.M., Roubik, D.W., Eds.; Springer International Publishing: Cham, Switzerland, 2018; pp. 377-390.

101. Da Silva, T.M.; Camara, C.A.; Lins, A.C.D.S.; Filho, J.M.B.; Da Silva, E.M.S.; Freitas, B.M.; DOS Santos, F.D.A.R. Chemical composition and free radical scavenging activity of pollen loads from stingless bee Melipona subnitida Ducke. J. Food Compos. Anal. 2006, 19, 507-511. [CrossRef]

102. Chen, A.Y.; Chen, Y.C. A review of the dietary flavonoid, kaempferol on human health and cancer chemoprevention. Food Chem. 2014, 138, 2099-2107. [CrossRef]

103. Li, Y.; Yao, J.; Han, C.; Yang, J.; Chaudhry, M.T.; Wang, S.; Liu, H.; Yin, Y. Quercetin, Inflammation and Immunity. Nutrients 2016, 8, 167. [CrossRef] [PubMed]

104. Othman, Z.A.; Ghazali, W.S.W.; Noordin, L.; Yusof, N.A.M.; Mohamed, M. Phenolic Compounds and the Anti-Atherogenic Effect of Bee Bread in High-Fat Diet-Induced Obese Rats. Antioxidants 2020, 9, 33. [CrossRef] [PubMed]

105. Lopes, A.J.O.; Vasconcelos, C.C.; Garcia, J.B.S.; Pinheiro, M.S.D.; Pereira, F.A.N.; Camelo, D.D.S.; De Morais, S.V.; Freitas, J.R.B.; Da Rocha, C.Q.; de Sousa Ribeiro, M.N.; et al. Anti-inflammatory and antioxidant activity of pollen extract collected by Scaptotrigona affinis postica: In silico, in vitro, and in vivo studies. Antioxidants 2020, 9, 103. [CrossRef] [PubMed]

106. Lopes, A.J.O.; Vasconcelos, C.C.; Pereira, F.A.N.; Silva, R.H.M.; Dos Santos Queiroz, P.F.; Fernandes, C.V.; Garcia, J.B.S.; Ramos, R.M.; Da Rocha, C.Q.; De Jesus Rodrigues Moreira Lima, S.T.; et al. Anti-Inflammatory and activity and antinociceptive activity of pollen extract collected by stingless bee Melipona fasciculata. Int. J. Mol. Sci. 2019, 20, 4512. [CrossRef]

107. Belina-Aldemita, M.D.; Schreiner, M.; D'Amico, S. Characterization of phenolic compounds and antioxidative potential of pot-pollen produced by stingless bees (Tetragonula biroi Friese) from the Philippines. J. Food Biochem. 2020, 44, e13102. [CrossRef]

108. Ide Melo, L.P.; de Almeida-Muradian, L.B. Stability of antioxidants vitamins in bee pollen samples. Quim. Nova 2010, 33, 514-518. [CrossRef] 
109. Oliveira, K.C.L.S.; Moriya, M.; Azedo, R.A.B.; Teixeira, E.W.; Alves, M.L.T.M.F.; Moreti, A.C.D.C.C.; De Almeida-Muradian, L.B. Relationship between Botanical origin and Antioxidants Vitamins of Bee-Collected Pollen. Quim. Nova 2009, 32, $1099-1102$. [CrossRef]

110. Nordin, A.; Sainik, N.Q.A.V.; Chowdhury, S.R.; Saim, A.B.; Idrus, R.B.H. Physicochemical properties of stingless bee honey from around the globe: A comprehensive review. J. Food Compos. Anal. 2018, 73, 91-102. [CrossRef]

111. Aldgini, H.M.M.; Al-Abbadi, A.A.; Abu-Nameh, E.S.M.; Alghazeer, R.O. Determination of metals as bio indicators in some selected bee pollen samples from Jordan. Saudi J. Biol. Sci. 2019, 26, 1414-1422. [CrossRef]

112. Carneiro, A.L.B.; Gomes, A.A.; Da Silva, L.A.; Alves, L.B.; Da Silva, E.C.; Pinto, A.C.D.S.; Tadei, W.P.; Pohlit, A.M.; Teixeira, M.F.S.; Gomes, C.C.; et al. Antimicrobial and Larvicidal Activities of Stingless Bee Pollen from Maues, Amazonas, Brazil. Bee World 2019, 96, 98-103. [CrossRef]

113. Akhir, R.A.M.; Bakar, M.F.A.; Sanusi, S.B. Antioxidant and antimicrobial activity of stingless bee bread and propolis extracts. AIP Conf. Proc. 2018, 42, 72-79. [CrossRef]

114. Sulbarán-Mora, M.; Pérez-Pérez, E.; Vit, P. Antibacterial Activity of Ethanolic Extracts of Pot-Pollen Produced by Eight Meliponine Species from Venezuela. In Pot-Pollen in Stingless Bee Melittology; Vit, P., Pedro, S.R.M., Roubik, D.W., Eds.; Springer International Publishing: Cham, Switzerland, 2018; pp. 391-399.

115. Reuter, S.; Gupta, S.C.; Chaturvedi, M.M.; Aggarwal, B.B. Oxidative stress, inflammation, and cancer. Free Radic. Biol. Med. 2011, 49, 1603-1616. [CrossRef] [PubMed]

116. Alam, M.N.; Bristi, N.J.; Rafiquzzaman, M. Review on in vivo and in vitro methods evaluation of antioxidant activity. Saudi Pharm. J. 2013, 21, 143-152. [CrossRef] [PubMed]

117. Chanda, S.; Dave, R. In vitro models for antioxidant activity evaluation and some medicinal plants possessing antioxidant properties: An overview. Afr. J. Microbiol. Res. 2009, 3, 981-996.

118. Eleazu, C.; Suleiman, J.B.; Othman, Z.A.; Zakaria, Z.; Nna, V.U.; Hussain, N.H.N.; Mohamed, M. Bee bread attenuates high fat diet induced renal pathology in obese rats via modulation of oxidative stress, downregulation of NF-kB mediated inflammation and Bax signalling. Arch. Physiol. Biochem. 2020, 1-17. [CrossRef]

119. Oltica, S.; Dezmirean, D.; Cluj-Napoca, V.M. Examination of Antioxidant Capacity of Beebread Extracts by Different Complementary Assays. Bull. Univ. Agric. Sci. Vet. Med. Cluj-Napoca 2007, 64, 204-207. [CrossRef]

120. Hudz, N.; Ivanova, R.; Brindza, J.; Grygorieva, O.; Schubertová, Z.; Ivanišová, E. Approaches to the determination of antioxidant activity of extracts from bee bread and safflower leaves and flowers. Potravin. Slovak J. Food Sci. 2017, 11, 480-488. [CrossRef]

121. World Health Organization. Obesity and Overweight. 2020. Available online: https://www.who.int/news-room/fact-sheets/ detail/obesity-and-overweight (accessed on 16 October 2020).

122. Carroll, M.J.; Brown, N.; Goodall, C.; Downs, A.M.; Sheenan, T.H.; Anderson, K.E. Honey bees preferentially consume freshly stored Pollen. PLoS ONE 2017, 12, e0175933. [CrossRef]

123. Anderson, K.E.; Carroll, M.J.; Sheehan, T.; Mott, B.M.; Maes, P.; Corby-Harris, V. Hive-stored pollen of honey bees: Many lines of evidence are consistent with pollen preservation, not nutrient conversion. Mol. Ecol. 2014, 23, 5904-5917. [CrossRef]

124. Ngalimat, M.S.; Rahman, R.N.Z.R.A.; Yusof, M.T.; Hamzah, A.S.A.; Zawawi, N.; Sabri, S. A review on the association of bacteria with stingless bees. Sains Malays. 2020, 49, 1853-1863. [CrossRef]

125. Narvhus, J.A.; Axelsson, L. Lactic acid bacteria. In The Encyclopedia of Food Sciences and Nutrition, 2nd ed.; Academic Press: Cambridge, MA, USA, 2003; pp. 3465-3472.

126. Mattila, H.R.; Rios, D.; Walker-sperling, V.E.; Roeselers, G.; Newton, I.L.G. Characterization of the Active Microbiotas Associated with Honey Bees Reveals Healthier and Broader Communities when Colonies are Genetically Diverse. PLoS ONE 2012, 7, e32962. [CrossRef] [PubMed]

127. Janashia, I.; Carminati, D.; Rossetti, L.; Zago, M.; Fornasari, M.E.; Haertlé, T.; Chanishvili, N.; Giraffa, G. Characterization of fructophilic lactic microbiota of Apis mellifera from the Caucasus Mountains. Ann. Microbiol. 2016, 66, 1387-1395. [CrossRef]

128. Asama, T.; Arima, T.-H.; Gomi, T.; Keishi, T.; Tani, H.; Kimura, Y.; Tatefuji, T.; Hashimoto, K. Lactobacillus kunkeei YB38 from honeybee products enhances IgA production in healthy adults. J. Appl. Microbiol. 2015, 119, 818-826. [CrossRef]

129. Vásquez, A.; Olofsson, T.C.; Sammataro, D.; Vásquez, A.; Olofsson, T.C.; Sammataro, D. A scientific note on the lactic acid bacterial flora in honeybees in the USA-A comparison with bees from Sweden. Apidologie 2009, 40, 26-28. [CrossRef]

130. Lozo, J.; Berić, T.; Terzić-Vidojević, A.; Stanković, S.; Fira, D.; Stanisavljević, L. Microbiota associated with pollen, bee bread, larvae and adults of solitary bee Osmia cornuta (Hymenoptera: Megachilidae). Bull. Entomol. Res. 2015, 105, 470-476. [CrossRef]

131. Endo, A.; Futagawa-Endo, Y.; Dicks, L.M.T. Isolation and characterization of fructophilic lactic acid bacteria from fructose-rich niches. Syst. Appl. Microbiol. 2009, 32, 593-600. [CrossRef]

132. Yaacob, S.N.S.; Huyop, F.; Ibrahim, R.K.R.; Wahab, R.A. Identification of Lactobacillus spp. and Fructobacillus spp. isolated from fresh Heterotrigona itama honey and their antagonistic activities against clinical pathogenic bacteria. J. Apic. Res. 2018, 57, 395-405. [CrossRef]

133. Endo, A.; Salminen, S. Honeybees and beehives are rich sources for fructophilic lactic acid bacteria. Syst. Appl. Microbiol. 2013, 36, 444-448. [CrossRef]

134. Rokop, Z.P.; Horton, M.A.; Newton, I.L.G. Interactions between Cooccurring Lactic Acid Bacteria in Honey. J. ASM 2015, 81, 7261-7270. [CrossRef] 
135. Janashia, I.; Alaux, C. Specific immune stimulation by endogenous bacteria in honey bees (Hymenoptera: Apidae). J. Econ. Entomol. 2016, 109, 1474-1477. [CrossRef]

136. Gilliam, M. Microbiology of Pollen and Bee Bread: The Genus Bacillus. Apidologie 1979, 10, 269-274. [CrossRef]

137. Rosa, C.A.; Lachance, M.-A.; Silva, J.O.; Teixeira, A.C.P.; Marini, M.M.; Antonini, Y.; Martins, R.P. Yeast communities associated with stingless bees. FEMS Yeast Res. 2003, 4, 271-275. [CrossRef]

138. Teixeira, A.C.P.; Marini, M.M.; Nicoli, J.R.; Antonini, Y.; Martins, R.P.; Lachance, M.-A.; Rosa, C.A. Starmerella meliponinorum sp. nov., a novel ascomycetous yeast species associated with stingless bees. Int. J. Syst. Evol. Microbiol. 2003, 53, 339-343. [CrossRef] [PubMed]

139. Daniel, H.-M.; Rosa, C.A.; Thiago-Calaça, P.S.S.; Antonini, Y.; Bastos, E.M.A.F.; Evrard, P.; Huret, S.; Fidalgo-Jiménez, A.; Lachance, M.-A. Starmerella neotropicalis f. a., sp. nov., a yeast species found in bees and pollen from Brazil and Cuba. Int. J. Syst. Evol. Microbiol. 2013, 63, 3896-3903. [CrossRef]

140. Gilliam, M.; Rubik, D.; Lorenz, B. Microorganisms associated with pollen, honey and brood provisions in the nest of a stingless bee, Melipona fasciata. Apidologie 2000, 21, 89-97. [CrossRef]

141. Ramos, H.C.; Hoffmann, T.; Marino, M.; Nedjari, H.; Presecan-Siedel, E.; Dreesen, O.; Glaser, P.; Jahn, D. Fermentative metabolism of Bacillus subtilis: Physiology and regulation of gene expression. J. Bacteriol. 2000, 182, 3072-3080. [CrossRef]

142. Aqeel, B.M.; Umar, D.M. Effect of Alternative Carbon and Nitrogen Sources on Production of Alpha-amylase by Bacillus megaterium. World Appl. Sci. J. 2010, 8, 85-90. [CrossRef]

143. Akcan, N. High Level Production of Extracellular $\alpha$-Amylase from Bacillus licheniformis ATCC 12759 in Submerged Fermentation. Rom. Biotechnol. Lett. 2011, 16, 6833-6840.

144. Gilliam, M. Microbiology of Pollen and Bee bread: The Yeasts. Apidologie 1979, 10, 43-53. [CrossRef]

145. Olofsson, T.C.; Vásquez, A. Detection and identification of a novel lactic acid bacterial flora within the honey stomach of the honeybee Apis mellifera. Curr. Microbiol. 2008, 57, 356-363. [CrossRef]

146. Anderson, K.E.; Sheehan, T.H.; Mott, B.M.; Maes, P.; Snyder, L.; Schwan, M.R.; Walton, A.; Jones, B.M.; Corby-Harris, V. Microbial Ecology of the Hive and Pollination Landscape: Bacterial Associates from Floral Nectar, the Alimentary Tract and Stored Food of Honey Bees (Apis mellifera). PLoS ONE 2013, 8, e83125. [CrossRef] [PubMed]

147. Corby-Harris, V.; Maes, P.; Anderson, K.E. The bacterial communities associated with honey bee (Apis mellifera) foragers. PLoS ONE 2014, 9, e95056. [CrossRef] [PubMed]

148. Kwong, W.K.; Moran, N.A. Gut microbial communities of social bees. Nat. Rev. Microbiol. 2016, 14, 374-384. [CrossRef] [PubMed]

149. Moran, N.A. Genomics of the honey bee microbiome. Curr. Opin. Insect Sci. 2015, 10, 22-28. [CrossRef]

150. Vásquez, A.; Forsgren, E.; Fries, I.; Paxton, R.J.; Flaberg, E.; Szekely, L.; Olofsson, T.C. Symbionts as major modulators of insect health: Lactic acid bacteria and honeybees. PLoS ONE 2012, 7, e33188. [CrossRef]

151. Leonhardt, S.D.; Kaltenpoth, M. Microbial Communities of Three Sympatric Australian Stingless Bee Species. PLoS ONE 2014, 9, e105718. [CrossRef]

152. Kwong, W.K.; Medina, L.A.; Koch, H.; Sing, K.-W.; Soh, E.J.Y.; Ascher, J.S.; Jaffé, R.; Moran, N.A. Dynamic microbiome evolution in social bees. Sci. Adv. 2017, 3, 1-17. [CrossRef]

153. Powell, J.E.; Martinson, V.G.; Urban-Mead, K.; Moran, N.A. Routes of acquisition of the gut microbiota of the honey bee Apis mellifera. Appl. Environ. Microbiol. 2014, 80, 7378-7387. [CrossRef]

154. Zheng, H.; Nishida, A.; Kwong, W.K.; Koch, H.; Engel, P.; Steele, M.I.; Moran, N.A. Metabolism of toxic sugars by strains of the bee gut symbiont Gilliamella apicola. mBio 2016, 7, 1-9. [CrossRef] 